\title{
“Rad bi bil bolj ..." Ali lahko namerno spremenimo svoje osebnostne lastnosti?
}

\author{
Gaja Zager Kocjan ${ }^{1 *}$ in Maruša Kekec ${ }^{2}$ \\ ${ }^{1}$ Oddelek za psihologijo, Filozofska fakulteta, Univerza v Ljubljani \\ ${ }^{2}$ Sveta Trojica
}

\begin{abstract}
Povzetek: V prispevku smo pregledali in kritično ovrednotili novejše raziskave s področja psihologije osebnosti, ki se osredotočajo na razumevanje in empirično preučevanje posameznikovega lastnega prizadevanja oziroma samoregulacije pri spreminjanju osebnostnih lastnosti. Raziskovalne članke za ta pregled literature smo iskali s pomočjo podatkovnih baz, vključenih v zbirko EBSCOhost, ter $\mathrm{v}$ bazah Web of Science, ScienceDirect in Scopus, in sicer pod ključnimi besednimi zvezami "namerne spremembe osebnosti" ali "hotene spremembe osebnosti”. Pregled 25 znanstvenih člankov, objavljenih med letoma 2012 in 2020, je pokazal, da si večina posameznikov želi spremeniti nekatere svoje osebnostne lastnosti ter da jih v razmeroma kratkem času dejansko lahko namerno spremenijo na podlagi specifičnih ciljev in načrta ter lastnega aktivnega prizadevanja za spremembo. Avtorji večinoma razumejo namerne spremembe osebnosti kot proces, ki poteka "od spodaj navzgor”, pri čemer glavni mehanizem predstavlja sprememba aktualnega vedenja, mišljenja in čustvovanja, ki se sčasoma manifestira v dolgotrajni spremembi osebnostnih lastnosti. Razvitih in preliminarno preizkušenih je bilo več intervencij za spodbujanje namernih sprememb osebnosti. Čeprav prve raziskave s tega področja kažejo obetavne rezultate, jim je skupnih več pomanjkljivosti. Mednje sodi zanašanje na metodo samoocenjevanja, majhnost in homogenost vzorcev ter razmeroma ozko časovno okno za spremljanje stabilnosti sprememb. Kljub nekaterim omejitvam izsledki prvih raziskav kažejo, da je namerno spreminjanje osebnosti v želeni smeri mogoče in ima lahko za posameznika ugodne posledice.
\end{abstract}

Ključne besede: namerne spremembe osebnosti, vseživljenjski osebnostni razvoj, velikih pet, intervencije

\section{"I want to be more ..." Can we intentionally change our personality traits?}

\author{
Gaja Zager Kocjan ${ }^{1 *}$ and Maruša Kekec ${ }^{2}$ \\ ${ }^{1}$ Department of Psychology, Faculty of Arts, University of Ljubljana, Slovenia \\ ${ }^{2}$ Sveta Trojica, Slovenia
}

\begin{abstract}
In this article, we reviewed and critically evaluated the latest research in the field of personality psychology that focuses on understanding and empirically examining a person's own effort or self-regulation as a source of personality trait change. Articles included in this literature review were found through EBSCOhost, Web of Science, ScienceDirect, and Scopus, using "volitional personality change" or "intentional personality change" as key words. The review of 25 scientific articles published between 2012 and 2020 has shown that most of the individuals want to change some of their personality traits, which is indeed possible in a relatively short period of time by investing deliberate effort and relying on specific goals and plans to change selected personality traits. In general, most authors understand volitional personality change as a "bottom-up" process with a main mechanism being a change in current behavior, thinking, and emotions that over time manifests in a long-term personality change. Several interventions have been developed and preliminary tested to promote volitional personality change. Although first studies in this area show some promising results, they have several limitations in common. Among those are reliance on self-reports, small size and homogeneity of samples, and short time frame to monitor stability of the observed changes. Despite the limitations, results from these studies suggest that intentionally changing one's personality may have beneficial consequences for an individual.
\end{abstract}

Keywords: volitional personality change, lifespan personality development, big five, interventions

\footnotetext{
${ }^{*}$ Naslov/Address: doc. dr. Gaja Zager Kocjan, Oddelek za psihologijo, Filozofska fakulteta, Univerza v Ljubljani, Aškerčeva 2, 1000 Ljubljana, email: gaja.zagerkocjan@ff.uni-lj.si

Članek je licenciran pod pogoji Creative Commons Attribution 4.0 International licence. (CC-BY licenca).

The article is licensed under a Creative Commons Attribution 4.0 International License (CC-BY license).
} 
V življenju si ljudje nemalokrat zaželimo, da bi bili drugačni. Želimo si, da bi imeli drugačne osebnostne lastnosti: da ne bi bili sramežljivi, da bi bili bolj prijateljski, da ne bi bili tako ljubosumni, da bi bili bolj odprti do drugih in še bi lahko naštevali. Ali je to res tako preprosto? Ali lahko namerno spremenimo svojo osebnost? Splošno privzeto je razumevanje osebnostnih lastnosti kot stabilnih vzrokov različnih življenjskih izidov (McCrae in Costa, 2008), ki jih okoljski vplivi in intervencije ne spreminjajo. Vendar pa raziskave kažejo, da se osebnost spreminja skozi vse življenje (Roberts idr., 2006) in da igrajo pri tem pomembno vlogo tudi okoljski dejavniki (Bleidorn idr., 2018) ter tako klinične (Roberts idr., 2017) kot neklinične intervencije (Sedlmeier idr., 2012). V zadnjih letih se pojavlja vedno več raziskav, ki se osredotočajo na preučevanje posameznikovega lastnega prizadevanja oziroma samoregulacije kot izvora osebnostnih sprememb. Na namerne spremembe osebnosti smo se osredotočili tudi $\mathrm{v}$ tem prispevku, katerega namen je predstaviti sistematični pregled znanstvene literature in ugotovitev na tem področju.

\section{Osebnostne lastnosti, njihova stabilnost in spremenljivost skozi življenje}

Osebnostne lastnosti so razmeroma stabilni, samodejni vzorci mišljenja, čustvovanja in vedenja, ki so tipični za posameznika $\mathrm{v}$ različnih situacijah in $\mathrm{v}$ katerih se posamezniki med seboj razlikujejo (Allport, 1961). V zadnjih letih se je pri preučevanju temeljnih osebnostnih lastnosti najbolj uveljavil petfaktorski model osebnosti (McCrae in Costa, 1985) oziroma model velikih pet (Goldberg, 1990), ki ga sestavljajo ekstravertnost, sprejemljivost, vestnost, čustvena stabilnost in odprtost. Čeprav osebnostne lastnosti razumemo kot relativno stabilne, se spreminjajo skozi vse življenje. Pri razumevanju njihove stabilnosti in spremenljivosti igrajo pomembno vlogo tako genetski kot okoljski oziroma kontekstualni dejavniki. Medtem ko so genetski vplivi pomembnejši v mladostništvu in zgodnji odraslosti, pozneje postajajo vse pomembnejši vplivi okolja (Briley in TuckerDrob, 2014). Izraženost večine osebnostnih lastnosti se v obdobju posameznikovega življenja spremeni za približno en standardni odklon, kar v psihologiji običajno velja za velik učinek (Roberts idr., 2006).

O normativnih vzorcih osebnostnega razvoja, ki jih verjetno lahko pripišemo biološkemu zorenju (Bleidorn idr., 2009) in skupnim življenjskim izkušnjam (npr. prehod iz študentskega $\mathrm{v}$ odraslo življenje $\mathrm{v}$ sodobnih tehnološko razvitih družbah; Lüdtke idr., 2011), govorimo, ko se ti ujemajo $\mathrm{s}$ populacijo in odražajo spremembe povprečnih ravni osebnostnih lastnosti v populaciji. Diferencialni vzorci osebnostnega razvoja pa so odraz ohranjanja ali sprememb rangov oziroma položaja posameznika glede na njegove vrstnike v času in edinstvenih sprememb v ravni izraženosti osebnostnih lastnosti pri posamezniku (Bleidorn idr., 2019; Geukes idr., 2019; Roberts in Mroczek, 2008). Raziskave so pokazale, da so normativne spremembe glede na druga razvojna obdobja znatne predvsem od mladostništva do zgodnje odraslosti, in sicer v smeri večje socialne in psihološke zrelosti, kar se kaže $\mathrm{v}$ upadu nevroticizma in porastu vestnosti, sprejemljivosti in odprtosti (Bleidorn, 2015). Delno lahko torej pri konkretnem mladostniku porast $\mathrm{v}$ vestnosti pripišemo normativni razvojni dinamiki, ki je povezana $\mathrm{z}$ biološkim procesom zorenja in zaključkom izobraževanja ter prehodom v svet dela. Vendar pa se lahko posamezniki med seboj razlikujejo v specifičnih izkušnjah ter odzivih na življenjske dogodke (Allemand idr., 2015) in v socialnih vlogah, ki jih prevzemajo (Hudson idr., 2012; Lehnart idr., 2010), kar sodoloča njihov diferencialni osebnostni razvoj (Roberts in Mroczek, 2008). Pomembni življenjski dogodki in spremembe socialnih vlog usmerjajo, zmotijo in spreminjajo življenjske poti ter tako vplivajo na posameznikove misli, vedenje in čustva, kar lahko sčasoma privede do trajnih sprememb osebnostnih lastnosti.

Ljudje se lahko med seboj razlikujejo tudi v svojih namernih prizadevanjih, da bi dosegli želeno spremembo osebnosti. Še posebej v okviru klinične in drugih aplikativnih področij psihologije obstaja široko sprejeto prepričanje, da imajo posamezniki aktivno vlogo pri svojem razvoju (Lang in Heckhausen, 2001). V zadnjem času se je ta ideja razširila in odrazila tudi v teorijah in raziskavah psihologije osebnosti, socialne in razvojne psihologije (Hudson in Roberts, 2014). Močno je razširjena tudi v širši družbi, kar se na primer kaže v priljubljenosti številnih knjig za samopomoč in delo na sebi.

\section{Kako pride do osebnostnih sprememb?}

Čeprav različne teorije naslavljajo vseživljenjski osebnostni razvoj (glej Specht idr., 2014), je manj znanega o kratkoročnih procesih, ki privedejo do dolgoročne stabilnosti in spremenljivosti osebnostnih lastnostih. $V$ zadnjih letih se je pojavilo več teorij procesov, ki privedejo do osebnostnih sprememb (npr. Geukes idr., 2018; Wrzus in Roberts, 2017). Skoraj vse pojasnjujejo spremembe osebnosti kot proces, ki poteka "od spodaj navzgor", njegova ključna sestavina pa so osebnostna stanja. Ta imajo enake čustvene, vedenjske in kognitivne komponente kot osebnostne lastnosti, le da trajajo manj časa (Fleeson, 2001). Razlikovanje osebnostnih lastnosti in stanj ter poznavanje njihove tesne povezave je ključno za razumevanje procesa osebnostnih sprememb.

Po novejšem modelu osebnostnih sprememb TESSERA (angl. Triggering situations, Expectancy, States/State Expressions, and ReActions; Wrzus in Roberts, 2017) je dolgotrajen osebnostni razvoj posledica kratkotrajnih, situacijskih procesov. Vsakodnevni dogodki, socialne vloge in z njimi povezane izkušnje ter vedenje drugih so primeri sprožilcev situacij, ki na posameznika delujejo od zunaj in se lahko pojavljajo v različnih kontekstih. Posameznikova trenutna motivacija (npr. nameni, cilji) določa, do kakšnega osebnostnega stanja bo prišlo v odziv na sprožilec situacije. Do spremembe osebnosti naj bi prišlo zaradi dolgotrajnih in ponavljajočih se vzorcev izražanja osebnostnih stanj, ki se razlikujejo od običajnih vedenj, misli in čustev, značilnih za posameznika z določenimi osebnostnimi lastnostmi. Reakcije na izražena stanja lahko izhajajo iz posameznika (ojačitev preko čustev) ali njegove okolice (ojačitev ali kaznovanje preko povratne informacije s strani drugih). Preko ojačitev se posamezne sekvence po modelu TESSERA obdržijo ali spreminjajo $\mathrm{v}$ času, kar privede do dolgotrajnih sprememb osebnosti (Wrzus in Roberts, 2017). 
Izhajajoč iz modela TESSERA, K. Geukes in sodelavci (2018) dodatno razlikujejo tri področja medosebnih razlik $\mathrm{v}$ procesih, povezanih $\mathrm{z}$ osebnostnimi stanji, ki se nanašajo na različne faze v regulaciji vedenja: (1) cilje in strategije, ki odražajo medosebne razlike $\mathrm{v}$ motivaciji, (2) aktivnosti in izkušnje, ki odražajo medosebne razlike $\mathrm{v}$ vedenju in kognitivno čustvenem procesiranju, ter (3) evalvacijo in refleksijo, ki odražata medosebne razlike v samopodobi, splošnih stališčih in vrednotah. Avtorji osebnostne lastnosti razumejo kot omrežja med seboj povezanih osebnostnih stanj, torej vzorcev čustvovanja, mišljenja in vedenja v specifičnih situacijah, ki težijo $\mathrm{k}$ medsebojnemu ravnovesju (brez predpostavke skupnega izvora $\mathrm{v}$ določeni latentni lastnosti; Cramer idr., 2012). Časovna stabilnost globalno ocenjenih osebnostnih lastnosti naj bi bila odraz razvoja stabilne konfiguracije omrežja osebnostnih stanj znotraj posameznika. Dolgotrajen osebnostni razvoj pa naj bi bil posledica odklona komponent sistema od uravnotežene konfiguracije, kar privede do sistematične spremembe medsebojno povezanih komponent, dokler se ne vzpostavi novo ravnovesje.

\section{Psihoterapija in neklinične intervencije kot izvor osebnostnih sprememb}

Mnogi posamezniki, ki se želijo spremeniti, se odločijo za psihoterapijo, in dosedanje študije kažejo na učinkovitost psihoterapije pri dolgotrajni spremembi osebnostnih lastnosti. Nedavna metaanaliza 207 študij je pokazala, da vodijo klinične intervencije do izrazitih sprememb osebnostnih lastnostih glede na razvojne standarde (predvsem nevroticizma, pri katerem se kaže upad za pol standardnega odklona) in da se te spremembe obdržijo v času (Roberts idr., 2017).

Posameznikom, ki nimajo duševnih težav, so lahko v pomoč pri spreminjanju osebnostnih lastnosti različni treningi, četudi niso specifično oblikovani za ta namen. Po osemtedenskem treningu čuječnosti je pri študentih medicine prišlo do povišanja vestnosti in čustvene stabilnosti (Krasner idr., 2009). Tudi za osemnajsturni trening čustvene kompetentnosti, usmerjen $\mathrm{v}$ krepitev prepoznavanja, izražanja, razumevanja, reguliranja in uporabe čustev, je bilo ugotovljeno, da izboljša čustveno delovanje pri dodiplomskih študentih, kar se je pokazalo $\mathrm{v}$ upadu nevroticizma in povišanju ekstravertnosti ter sprejemljivosti, in sicer $\mathrm{v}$ obdobju šestih tednov po intervenciji (Nelis idr., 2011). Podobno je trening spretnosti (poklicne spretnosti, veščine spoprijemanja, duhovni razvoj in socialne spretnosti) pri udeležencih, ki so bili na šesttedenskem programu odvajanja od drog, privedel do značilnega povišanja čustvene stabilnosti, vestnosti, odprtosti, ekstravertnosti in sprejemljivosti. Na dimenzijah čustvene stabilnosti, vestnosti in sprejemljivosti so se spremembe ohranile še 15 mesecev po intervenciji (Piedmont, 2001). Tudi za meditacijo je metaanaliza (Sedlmeier idr., 2012) pokazala, da učinkuje na zmanjšanje anksioznosti in nevroticizma ter v manjši meri tudi nekaterih drugih manj prilagojenih osebnostnih lastnosti (npr. egoizem, dominantnost, psihoticizem).

Nekatere raziskave so preučevale vlogo kognitivnega treninga pri spreminjanju osebnosti. S kognitivnim treningom, ki je običajno usmerjen na specifično področje kognitivnega delovanja, skušamo izboljšati kognitivne sposobnosti posameznikov. Najbolj je raziskana njegova povezava z odprtostjo za izkušnje. Na vzorcu starejših odraslih je kognitivni trening $\mathrm{v}$ obdobju tridesetih tednov poleg izboljšanja $\mathrm{v}$ fluidni kognitivni sposobnosti induktivnega zaznavanja privedel tudi do višje odprtosti za nove izkušnje (Jackson idr., 2012). Vendar teh ugotovitev ne potrjujejo vse raziskave. Približno sto dni trajajoč kognitivni trening, usmerjen na spomin in zaznavno hitrost, namreč ni imel trajnega učinka na spremembo odprtosti za izkušnje pri vzorcih mlajših in starejših odraslih, morda zaradi uporabe manj primernih kognitivnih nalog (Sander idr., 2017).

\section{Samoregulacija kot izvor osebnostnih sprememb}

$\mathrm{V}$ zadnjem času se zanimanje za preučevanje posameznikove aktivne vloge $\mathrm{v}$ njegovem razvoju vse bolj prenaša s klinične in aplikativnih vej psihologije na področja psihologije osebnosti, socialne in razvojne psihologije (Hudson in Roberts, 2014). Predvsem med avtorji, ki preučujejo dinamiko osebnostnega razvoja, je opaziti porast zanimanja za vlogo posameznikovega lastnega prizadevanja oziroma samoregulacije pri doseganju osebnostnih sprememb, oziroma za tako imenovane namerne ali hotene spremembe osebnostnih lastnostih, ki jih lahko sami dosežemo v relativno kratkem obdobju brez pomoči terapije ali svetovanja (Dennisen in Penke, 2008).

$\mathrm{Na}$ to, da imamo ljudje različne cilje za spremembo osebnostnih lastnosti, je mogoče sklepati že na podlagi Higginsa (1987), ki je govoril o idealnem, moralnem in neželenem jazu, ki predstavljajo standarde, $\mathrm{h}$ katerim posameznik teži oziroma se jih izogiba. Večje kot je posameznikovo nezadovoljstvo $\mathrm{z}$ različnimi področji življenja, vključno z njegovimi osebnostnimi lastnostmi, večja naj bi bila razlika med njegovim realnim in idealnim jazom. Taki posamezniki lahko oblikujejo cilje za spremembo svojih osebnostnih lastnosti, saj menijo, da jim bo to pomagalo razrešiti njihovo nezadovoljstvo (Kiecolt, 1994). Želje za spremembo osebnostnih lastnosti lahko učinkujejo na trenutne vzorce misli, čustev in vedenja posameznika (Dennisen in Penke, 2008) in tako skozi čas prispevajo k razvoju oziroma trajni spremembi osebnostnih lastnosti (Hennecke idr., 2014).

Nekateri avtorji so se v zadnjih letih usmerili k empiričnemu preučevanju ciljev za spremembo osebnostnih lastnosti, pri tem pa so uporabili tako kvantitativne kot kvalitativne metode (Baranski idr., 2017, 2020; Hudson in Roberts, 2014). Raziskovalcev pa ni zanimalo le, ali se ljudje želijo spremeniti, ampak so, izhajajoč iz ugotovitev o vseživljenjskem razvoju in spremenljivosti osebnostnih lastnosti, želeli preučiti tudi, ali in kako lahko želene spremembe dejansko dosežejo (Hudson in Fraley, 2015, 2016a; Robinson idr., 2015). Nekateri so se usmerili k razvoju različnih nekliničnih intervencij za doseganje namernih osebnostnih sprememb ter k preučevanju njihove učinkovitosti (Magidson idr., 2014; Martin idr., 2014a, 2014b). 


\section{Raziskovalni problem}

Preučevanje vloge posameznikovega lastnega prizadevanja pri doseganju osebnostnih sprememb je pomembno tako $\mathrm{v}$ kontekstu teoretičnega razumevanja dinamike vseživljenjskega osebnostnega razvoja kot tudi v praktičnem pogledu, saj se osebnost povezuje $z$ vrsto pomembnih življenjskih izidov, vključno $\mathrm{z}$ zdravjem in psihičnim blagostanjem (Bleidorn idr., 2019). V tem prispevku skušamo preko sistematičnega pregleda literature o namernih spremembah osebnostnih lastnosti strniti ugotovitve dosedanjih raziskav na to temo in odgovoriti na vprašanja, a) ali si posamezniki želijo spremeniti svojo osebnost, katere lastnosti si najbolj želijo spremeniti in zakaj; b) ali lahko posamezniki svoje osebnostne lastnosti namerno spremenijo; c) kateri so dejavniki namernih sprememb osebnostnih lastnostih ter ciljev za spremembo; d) katere so in kako učinkovite so različne neklinične intervencije za namerno spreminjanje osebnostnih lastnosti? $\mathrm{V}$ prispevku kritično predstavimo pomanjkljivosti dosedanjih študij o namernih spremembah osebnosti ter navedemo predloge za prihodnje raziskave na tem področju.

\section{Metoda}

Pri metodologiji izbora člankov smo sledili smernicam modela PRISMA (Moher idr., 2009). Pregled literature je obsegal iskanje recenziranih člankov $\mathrm{v}$ angleškem jeziku $\mathrm{V}$ vseh podatkovnih bazah, vključenih v zbirko EBSCOhost, ter $\mathrm{v}$ bazah Web of Science, ScienceDirect in Scopus. Zadetke smo iskali pod ključnimi besednimi zvezami "namerne spremembe osebnosti" ali "hotene spremembe osebnosti". Skupaj smo dobili 79 zadetkov. Po izključitvi vseh podvojenih zadetkov smo pregledali naslove in povzetke preostalih 51 prispevkov ter izključili vse, ki niso ustrezali vključitvenim kriterijem oziroma so izpolnjevali pogoje za izključitev:

1. Vključili smo le znanstvene članke in izključili vse druge oblike prispevkov, kot so uvodniki številk znanstvenih revij, informacije o prihajajočih člankih, komentarji ipd.

2. Vključili smo le članke, ki so kot osrednjo temo preučevali namerne spremembe osebnosti. Članki, ki so spremembe osebnosti naslavljali širše ali bolj splošno, so bili izključeni iz pregleda literature.

3. Izključili smo več člankov (predvsem najdenih $\mathrm{v}$ bazi Scopus), v katerih namerne spremembe osebnosti niso bile predmet preučevanja, ampak so bile le postransko omenjene, na primer v kontekstu predlogov za nadaljnje študije.

4. Izključili smo vse članke, v katerih so bili preučevani klinični vzorci udeležencev. Izjema je članek J. Magidson in sodelavcev (2014), ki so s študijo primera intervencijo za spreminjanje vestnosti preizkusili na udeležencu, odvisnem od opiatov, saj naj bi bila intervencija namenjena tudi zdravim posameznikom.

Skupaj je bilo v tej fazi izključenih 25 prispevkov. Pri nekaterih člankih, predvsem teoretskih, na podlagi pregleda naslovov in povzetkov nismo mogli oceniti njihove relevantnosti. Zato smo po pregledu celotnih besedil preostalih 26 člankov, izključili še pet člankov. Ostalo nam je 21 člankov, ki so izpolnjevali vse vključitvene kriterije. Pregledali smo še sezname referenc teh člankov in med njimi izbrali štiri dodatne članke, ki so ustrezali vključitvenim kriterijem. Skupaj smo tako identificirali 25 člankov, objavljenih med letoma 2012 in 2020, ki smo jih vključili v pregled literature. Celoten potek iskanja člankov je prikazan na sliki 1.

\section{Rezultati in razprava}

Tabela 1 prikazuje povzetek ključnih elementov 25 znanstvenih člankov, vključenih $\mathrm{v}$ pregled literature. Za vsakega je naveden cilj oziroma problem, ki ga naslavlja, povzete so tudi ključne ugotovitve. Pri empiričnih člankih so poleg tega predstavljene glavne značilnosti vzorcev udeležencev ter navedeni uporabljeni merski pripomočki.

Pregled literature je pokazal, da se namerne oziroma hotene spremembe osebnosti kot samostojna tema in osrednji raziskovalni problem v literaturi, vsaj pod tem imenom, pojavljajo od leta 2012 dalje, čeprav lahko zametke ideje, da je mogoče osebnostne lastnosti namerno spremeniti $\mathrm{z}$ lastnim prizadevanjem, najdemo že pred tem (Kiecolt, 1994). Tudi sodobni pogledi na razvoj osebnosti poudarjajo pomen posameznikove motivacije pri razumevanju njegovega vedenja, mišljenja in čustvovanja, pa tudi oblikovanja osebnosti v času (Hennecke idr., 2014). Novejše raziskave preučujejo predvsem velikost in naravo ciljev za spremembo osebnosti in dejanske spremembe osebnostnih lastnostih na osnovi namernega prizadevanja, nekatere pa se osredotočajo tudi na razvoj in preizkušanje intervencij za namerno spreminjanje osebnosti. Ugotovitve pregledanih raziskav smo strnili in povzeli v obliki odgovorov na štiri širša vprašanja, ki smo si jih zastavili v raziskovalnem problemu.

\section{Ali želimo spremeniti svoje osebnostne lastnosti, katere lastnosti želimo spremeniti in zakaj?}

V eni prvih raziskav o ciljih za spremembo osebnosti sta Hudson in Roberts (2014) na podlagi vprašalnika velikih pet BFI (angl. Big Five Inventory; John idr., 1991) razvila samoocenjevalni pripomoček C-BFI (angl. Change Big Five Inventory), s katerim sta na vzorcu ameriških študentov ugotovila, da si je večina želela spremeniti nekatere osebnostne lastnosti, najbolj čustveno stabilnost in vestnost. Z uporabo drugačnega inštrumenta, BF-TGI (angl. Big Five TraitChange Goal Inventory), ki cilje za spremembo vsake osebnostne dimenzije meri z eno postavko, so na vzorcih mladih odraslih Britancev, Kitajcev in Irancev do podobnih zaključkov prišli tudi Robinson in sodelavci (2015). Avtorji obeh raziskav so ugotovili tudi, da med posamezniki močno prevladujejo cilji za spremembo v bolj socialno zaželeni smeri. Kot je pokazala kvalitativna študija, so cilji za spremembo osebnosti pogosti tudi v širšem kontekstu različnih življenjskih ciljev (Miller idr., 2019).

S faktorsko analizo sta Hudson in Roberts (2014) pokazala, da imajo cilji za spremembo osebnostnih lastnosti, kot sta jih merila $\mathrm{z}$ vprašalnikom $\mathrm{C}$-BFI, petfaktorsko strukturo 


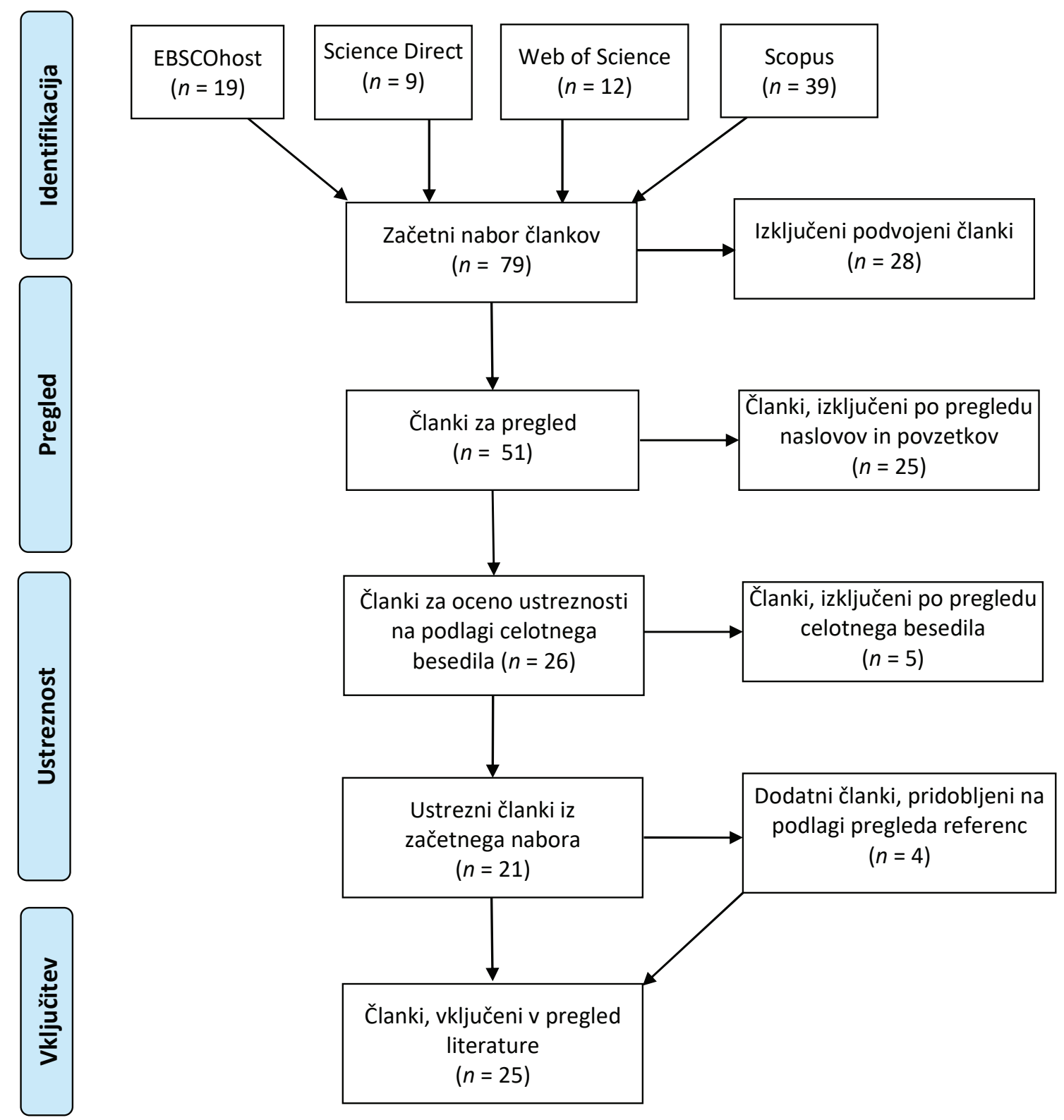

Slika 1. PRISMA diagram s strategijo iskanja člankov.

in se vsebinsko ujemajo $\mathrm{z}$ velikimi petimi dimenzijami osebnosti. Tudi, ko so udeleženci v kvalitativni študiji prosto opisovali svoje cilje za spremembo osebnosti, so avtorji te cilje klasificirali in interpretirali $\mathrm{v}$ skladu s petfaktorskim modelom osebnosti, z izjemo odprtosti (Baranski idr., 2017).

Različni avtorji ugotavljajo, da so cilji za spremembo osebnosti večinoma negativno povezani s trenutno ravnjo izraženosti osebnostnih lastnosti (Baranski idr., 2017; Hudson in Fraley, 2015, 2016a; Robinson idr., 2015; Quintus idr., 2017). Bolj introvertni posamezniki si na primer želijo postati bolj ekstravertni. Te ugotovitve se po mnenju Hudsona in Robertsa (2014) ujemajo s socialno zaželenostjo večine temeljnih osebnostnih lastnosti (Dunlop idr., 2012) in njihovo povezanostjo s socialno in psihološko zrelostjo (Roberts in Wood, 2006).

Skladno z ugotovitvami, da je osebnostni razvoj najbolj izrazit v zgodnji odraslosti, so raziskave pokazale, da imajo starejši posamezniki manj ciljev za spremembo osebnostnih lastnosti in da so pri njih cilji za spremembo nekoliko manjši, čeprav večina izraža željo po spremembi (Hudson in Fraley, 2016b; Quintus idr., 2017). Nekoliko večje cilje za spremembo pri mladih odraslih lahko povežemo z njihovo vlogo pri spodbujanju razvoja identitete in psihološke zrelosti (Roberts in Wood, 2006). Medtem ko so pri mladih najbolj izraziti cilji za spremembo vestnosti in čustvene stabilnosti, starejši približno enak pomen pripisujejo ciljem za spremembo vseh velikih pet (Hudson in Fraley, 2016b).

Pri postavljanju ciljev za spremembo osebnosti ima pomembno vlogo tudi perspektiva drugih. Posamezniki so imeli večji cilj spremeniti svoje osebnostne lastnosti takrat, kadar so te lastnosti pri njih drugi ocenili kot nizke in ko je bilo ujemanje med samoocenami in ocenami drugih večje (Quintus, idr., 2017). Drugi nam posredujejo povratne informacije (lahko tudi le posredno preko vedenjske interakcije) v zvezi s trenutno izraženostjo in želeno ravnjo naših osebnostnih lastnosti, na katere se lahko odzovemo s 
Tabela 1. Ključni elementi znanstvenih člankov, vključenih v pregled literature

\begin{tabular}{|c|c|c|c|c|}
\hline $\begin{array}{l}\text { Avtorji in } \\
\text { letnica }\end{array}$ & Cilj/problem & Značilnosti vzorca & $\begin{array}{l}\text { Uporabljeni } \\
\text { pripomočki }\end{array}$ & Glavne ugotovitve \\
\hline $\begin{array}{l}\text { Martin idr. } \\
(2012)\end{array}$ & $\begin{array}{l}\text { Oceniti zaželenost in } \\
\text { izvedljivost namernih } \\
\text { sprememb osebnosti ter } \\
\text { preučiti vlogo usmerjanja } \\
\text { (angl. coaching) pri } \\
\text { njihovem spodbujanju. }\end{array}$ & Teoretični članek & 1 & $\begin{array}{l}\text { Spremembe osebnosti v } \\
\text { razmeroma kratkih intervalih } \\
\text { so mogoče in so blagodejne } \\
\text { za posameznika. Pri njihovem } \\
\text { spodbujanju je lahko koristna } \\
\text { pomoč usmerjanja. }\end{array}$ \\
\hline $\begin{array}{l}\text { Allan idr. } \\
(2014)\end{array}$ & $\begin{array}{l}\text { Preučiti značilnosti } \\
\text { posameznikov, ki se } \\
\text { odločijo za sodelovanje v } \\
\text { intervenciji za spremembo } \\
\text { osebnostnih lastnosti. }\end{array}$ & $\begin{array}{l}N=54(83 \% \text { Ž }), \\
M_{\text {star. }}=42,2 \text { let. }\end{array}$ & NEO PI-R & $\begin{array}{l}\text { Posamezniki, ki so bili } \\
\text { motivirani za spremembo } \\
\text { osebnosti, so imeli višje } \\
\text { izraženo odprtost in } \\
\text { nevroticizem v primerjavi z } \\
\text { normativno populacijo. }\end{array}$ \\
\hline $\begin{array}{l}\text { Hennecke idr. } \\
\text { (2014) }\end{array}$ & $\begin{array}{l}\text { Predstaviti ključne pogoje, } \\
\text { preko katerih je mogoče } \\
\text { s samoregulacijo doseči } \\
\text { namerne spremembe } \\
\text { osebnosti. }\end{array}$ & Teoretični članek & l & $\begin{array}{l}\text { Ključni pogoji za spremembo } \\
\text { so (1) želja po spremembi, } \\
\text { (2) izvedljivost sprememb, } \\
\text { (3) želene spremembe morajo } \\
\text { postati nekaj vsakdanjega. }\end{array}$ \\
\hline $\begin{array}{l}\text { Hudson in } \\
\text { Roberts (2014) }\end{array}$ & $\begin{array}{l}\text { Empirično raziskati } \\
\text { posameznikove cilje za } \\
\text { spremembo osebnostnih } \\
\text { lastnosti. }\end{array}$ & $\begin{array}{l}\text { Študija } 1: N=264(53 \% \check{Z}), \\
M_{\text {star. }}=19,3 \text { let. } \\
\text { Studija } 2: N=162(50 \% \check{Z}) \text {, } \\
M_{\text {star. }}=19,3 \text { let. } \\
\text { Studija } 3: N=178(83 \% \check{Z}) \text {, } \\
M_{\text {star. }}=25,8 \text { let. } \\
\text { Studija } 4: N=314(76 \% \check{Z}), \\
M_{\text {star. }}=30,3 \text { let. }\end{array}$ & $\begin{array}{l}\text { BFI, C-BFI, SWLS, } \\
\text { mera vsakodnevnega } \\
\text { vedenja DBQ, } \\
\text { mera posplošenih z } \\
\text { osebnostjo povezanih } \\
\text { motivov M-BFI }\end{array}$ & $\begin{array}{l}\text { Večina udeležencev si je } \\
\text { želela spremembe osebnostnih } \\
\text { lastnosti v socialno zaželeni } \\
\text { smeri (najbolj povečati } \\
\text { čustveno stabilnost in vestnost). } \\
\text { Cilji za spremembo so bili } \\
\text { povezani z nezadovoljstvom na } \\
\text { določenih področjih življenja. } \\
\text { Negativno so se povezovali z } \\
\text { vsakodnevnim vedenjem in se } \\
\text { razlikovali od posplošenih z } \\
\text { osebnostjo povezanih motivov. }\end{array}$ \\
\hline $\begin{array}{l}\text { Magidson idr. } \\
\text { (2014) }\end{array}$ & $\begin{array}{l}\text { Predstavitev treninga } \\
\text { za krepitev vestnosti, } \\
\text { ki temelji na tehniki } \\
\text { vedenjske aktivacije, ter } \\
\text { preizkus treninga v obliki } \\
\text { študije primera. }\end{array}$ & $\begin{array}{l}\text { Študija primera: } \\
\text { 45-letni M z odvisnostjo od } \\
\text { opiatov }\end{array}$ & 1 & $\begin{array}{l}\text { Vedenje se je po } 12 \text {-tedenski } \\
\text { intervenciji močno spremenilo } \\
\text { in izboljšalo v smeri večje } \\
\text { vestnosti. }\end{array}$ \\
\hline $\begin{array}{l}\text { Martin idr. } \\
(2014 a)\end{array}$ & $\begin{array}{l}\text { Predstaviti razvoj } \\
\text { večstopenjskega } \\
\text { usmerjenja/treninga } \\
\text { namernih sprememb } \\
\text { osebnosti. }\end{array}$ & $\begin{array}{l}\text { Kvalitativni pristop } \mathrm{k} \\
\text { razvoju treninga: } \\
5 \text { psihologov in } 3 \text { klinični } \\
\text { psihologi }\end{array}$ & $\begin{array}{l}\text { NEO PI-R, } \\
\text { polstrukturiran } \\
\text { intervju }\end{array}$ & $\begin{array}{l}\text { Razviti in predstavljeni so } \\
\text { glavni koraki treninga namernih } \\
\text { sprememb osebnosti. }\end{array}$ \\
\hline $\begin{array}{l}\text { Martin idr. } \\
(2014 b)\end{array}$ & $\begin{array}{l}\text { Pilotno preučiti učinek 10- } \\
\text { tedenskega strukturiranega } \\
\text { treninga namernih } \\
\text { sprememb osebnosti } \\
\text { na facete osebnosti } \\
\text { (intervencija s kontrolno } \\
\text { skupino). }\end{array}$ & $\begin{array}{l}N=54(85 \% \text { Ž }), \\
M_{\text {star. }}=42,2 \text { let. }\end{array}$ & NEO PI-R & $\begin{array}{l}\text { Trening pomaga pri doseganju } \\
\text { želenih sprememb osebnostnih } \\
\text { lastnostih. Spremembe se } \\
\text { ohranijo še tri mesece po } \\
\text { zaključku treninga. }\end{array}$ \\
\hline $\begin{array}{l}\text { Hudson in } \\
\text { Fraley (2015) }\end{array}$ & $\begin{array}{l}\text { Ugotoviti, ali je mogoče } \\
\text { doseči želene spremembe } \\
\text { osebnosti in ali so cilji za } \\
\text { spremembo povezani z } \\
\text { dejanskimi spremembami } \\
\text { skozi čas (intervencija s } \\
\text { kontrolno skupino). }\end{array}$ & $\begin{array}{l}\text { Študija } 1: N=135(65 \% \check{Z}), \\
M_{\text {star. }}=20,2 \text { let. } \\
\text { Studija } 2: N=151(56 \% \text { Ž }), \\
M_{\text {star. }}=20,1 \text { let. }\end{array}$ & $\begin{array}{l}\text { BFI, NEO PI-R, IPIP- } \\
\text { 120, C-BFI, DBQ }\end{array}$ & $\begin{array}{l}\text { Pri udeležencih je po 4- } \\
\text { mesecih prišlo do spremembe } \\
\text { osebnostnih lastnosti v } \\
\text { želeni smeri. Pri spodbujanju } \\
\text { sprememb je bila učinkovita } \\
\text { intervencija/trening razvoja } \\
\text { veščin načrtovanja in } \\
\text { oblikovanja načrtov za } \\
\text { doseganje ciljev za spremembo } \\
\text { osebnosti. }\end{array}$ \\
\hline
\end{tabular}




\begin{tabular}{llll}
\hline Martin idr. & Raziskati izkušnje & Kvalitativna raziskava: & Polstrukturirani \\
$(2015)$ & udeležencev 10-tedenskega & $N=32(81 \%$ Ž $)$, & intervjuji; metoda \\
& namernih sprememb & $M_{\text {star. }}=42,2$ let. & induktivne tematske \\
& osebnosti. & & analize.
\end{tabular}

\section{Robinson idr.}

(2015)
Raziskati cilje in načrte za spremembo osebnostnih lastnosti med mladimi odraslimi iz Anglije, Irana in Kitajske.
Študija 1: $N=292(62 \%$ Ž), BFI, BF-TGI, $M_{\text {star. }}=22$ let. Studija $2: N=445(58 \% \check{Z})$, $M_{\text {star }}=23$ let. Študija 3: $N=177(57 \% \check{Z})$, $M_{\text {star. }}=22$ let. Študija $4: N$ 18-28 let. lestvica avtentičnosti, sprejemanje sebe (PWB), diskrepance

jazov, odprta vprašanja o načrtih za spremembo

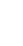
Udeleženci so trening doživeli kot proces, ki vodi k večjemu samozavedanju in bolj avtentičnemu načinu življenja, ter ga ocenili kot koristnega. Večina udeležencev si je želela spremeniti svoje osebnostne lastnosti in je imela specifičen načrt, kako doseči spremembe. Več ciljev za spremembo so imeli posamezniki iz kolektivističnih kultur. Povezave med cilji in dejanskimi spremembami v obdobju enega leta ni bilo ali so bile obratne od pričakovanih.

\begin{tabular}{llll}
\hline Hudson in & Raziskati vzdolžno & Vzdolžna raziskava: & BFI, C-BFI \\
Fraley (2016a) & povezanost psihičnega & $N=158$ (udeleženci, ki so & \\
& blagostanja in namernih & sodelovali pri vsaj eni od & \\
& sprememb osebnosti v & 16 meritev z enotedenskim & \\
& obdobju 4 mesecev. & razmikom)
\end{tabular}

\begin{tabular}{llll}
\hline Hudson in $\quad$ Ugotoviti, ali se cilji za & $N=6800(72 \%$ Ž), & BFI, C-BFI
\end{tabular}

Fraley (2016b) spremembo osebnostnih $\quad M_{\text {star. }}=28,4$ let. lastnosti spreminjajo glede na starost. Nezadovoljstvo lahko povzroči pojav ciljev za spremembo. Pri udeležencih, ki so svoje osebnostne lastnosti spremenili $\mathrm{v}$ želeno smer, je prišlo do porasta v blagostanju. Tudi starejši si želijo sprememb osebnosti, čeprav je velikost in prevalenca njihovih ciljev manjša. Pri mladih so najbolj izraziti cilji za spremembo vestnosti in čustvene stabilnosti, starejši pa približno enak pomen pripisujejo ciljem za spremembo vseh velikih pet.

\begin{tabular}{|c|c|c|c|c|}
\hline $\begin{array}{l}\text { Allemand } \\
\text { in Flückiger } \\
(2017)\end{array}$ & $\begin{array}{l}\text { Preučiti vlogo in } \\
\text { mehanizme nekliničnih } \\
\text { intervencij pri namernem } \\
\text { spreminjanju osebnosti } \\
\text { in jih povezati z izsledki } \\
\text { raziskav s področja } \\
\text { psihoterapije. }\end{array}$ & Teoretični članek & l & $\begin{array}{l}\text { Argumentiranje štirih } \\
\text { mehanizmov, preko katerih } \\
\text { lahko neklinične intervencije } \\
\text { pri zdravih posameznikih } \\
\text { vodijo do namernih sprememb } \\
\text { osebnosti. }\end{array}$ \\
\hline $\begin{array}{l}\text { Baranski idr. } \\
(2017)\end{array}$ & $\begin{array}{l}\text { Raziskati laična prepričanja } \\
\text { o namernih spremembah } \\
\text { osebnosti in strategije, ki } \\
\text { jih ljudje uporabljajo, da bi } \\
\text { dosegli želene spremembe. } \\
\text { Preučiti dejavnike } \\
\text { sprememb v preteklosti } \\
\text { in ciljev za spremembo v } \\
\text { sedanjosti. }\end{array}$ & $\begin{array}{l}\text { Kvalitativna raziskava: } \\
\text { Študija } 1: N=602, \\
M_{\text {star. }}=31,2 . \\
\text { Studija } 2: N=578, \\
M_{\text {star. }}=37,5\end{array}$ & $\begin{array}{l}\text { Odprta vprašanja } \\
\text { (cilji za spremembo, } \\
\text { strategije za } \\
\text { spremembo, dejavniki } \\
\text { sprememb/ciljev za } \\
\text { spremembo), BFI }\end{array}$ & $\begin{array}{l}\text { Posamezniki uporabljajo } \\
\text { različne strategije, da bi dosegli } \\
\text { želene spremembe osebnostnih } \\
\text { lastnostih (kognitivne vs. } \\
\text { vedenjske). Najpogostejši } \\
\text { dejavniki trenutnih ciljev } \\
\text { za spremembo so specifični } \\
\text { pretekli dogodki, razlogi } \\
\text { preteklih sprememb pa } \\
\text { spremembe socialnih vlog. }\end{array}$ \\
\hline $\begin{array}{l}\text { Quintus idr. } \\
\text { (2017) }\end{array}$ & $\begin{array}{l}\text { Raziskati povezanost } \\
\text { ciljev za spremembo s } \\
\text { samooceno osebnostnih } \\
\text { lastnosti in z oceno } \\
\text { pomembnih drugih ter } \\
\text { z nekaterimi drugimi } \\
\text { dejavniki. }\end{array}$ & $\begin{array}{l}\text { Vzorec } 1: N=254 \\
(75 \% \check{Z}), M_{\text {star. }}=21,9 \text { let. } \\
\text { Vzorec } 2: N=124 \\
(69 \% \check{Z}), M_{\text {star. }}=67,9 \text { let. }\end{array}$ & $\begin{array}{l}\text { BFI, C-BFI, SWLS, } \\
\text { RSE, IE-4, LOT- } \\
\text { R, UCLA lestvica } \\
\text { osamljenosti, mera } \\
\text { implicitne teorije } \\
\text { spremenljivosti } \\
\text { osebnostnih lastnosti }\end{array}$ & $\begin{array}{l}\text { Velikost ciljev za spremembo } \\
\text { osebnostnih lastnosti je bila } \\
\text { povezana s samoocenami } \\
\text { teh lastnosti in z ocenami } \\
\text { pomembnih drugih. Spremembe } \\
\text { so si bolj prizadevali } \\
\text { doseči tisti, ki so bili manj } \\
\text { optimistični, bolj osamljeni, } \\
\text { bolj nezadovoljni z življenjem } \\
\text { in so imeli manjši občutek } \\
\text { nadzora nad situacijo. }\end{array}$ \\
\hline
\end{tabular}




\begin{tabular}{|c|c|c|c|c|}
\hline $\begin{array}{l}\text { Allan idr. } \\
(2018)\end{array}$ & $\begin{array}{l}\text { Bolj poglobljeno in } \\
\text { sistematično preučiti } \\
\text { učinke pilotne izvedbe } \\
\text { 10-tedenskega treninga } \\
\text { namernih sprememb } \\
\text { osebnostnih lastnostih } \\
\text { (intervencija s kontrolno } \\
\text { skupino). }\end{array}$ & $\begin{array}{l}N=54(85 \% \text { Ž }) \\
M_{\text {star. }}=42,2 \text { let. }\end{array}$ & NEO PI-R & $\begin{array}{l}\text { Trening je privedel do } \\
\text { povišanja ekstravertnosti } \\
\text { in vestnosti ter znižanja } \\
\text { nevroticizma. Spremembe } \\
\text { niso bile posledica splošnega } \\
\text { učinka intervencije, ampak } \\
\text { usmerjenosti v spremembo } \\
\text { specifičnih osebnostnih } \\
\text { lastnosti (angl. targeting). }\end{array}$ \\
\hline $\begin{array}{l}\text { Stieger idr. } \\
(2018)\end{array}$ & $\begin{array}{l}\text { Predstaviti mobilno } \\
\text { aplikacijo PEACH, } \\
\text { namenjeno 10-tedenskemu } \\
\text { usmerjanju za namerno } \\
\text { spreminjanje osebnosti, ter } \\
\text { protokol študije za preizkus } \\
\text { učinkovitosti aplikacije. }\end{array}$ & $\begin{array}{l}\text { Teoretični članek z načrtom } \\
\text { raziskave. }\end{array}$ & $\begin{array}{l}\text { PEACH mobilna } \\
\text { aplikacija }\end{array}$ & $\begin{array}{l}\text { Aplikacija omogoča prilagojeno } \\
\text { ocenjevanje in intervencije } \\
\text { v vsakodnevnem življenju. } \\
\text { Načrtovan je } 2 \times 2 \text { faktorski } \\
\text { naključni nadzorovani poskus } \\
\text { z neponovljenimi meritvami in } \\
\text { vzdolžno zasnovo. }\end{array}$ \\
\hline $\begin{array}{l}\text { Martin-Allan } \\
\text { idr. (2019) }\end{array}$ & $\begin{array}{l}\text { Ugotoviti dolgotrajne } \\
\text { učinke treninga namernih } \\
\text { sprememb osebnosti. }\end{array}$ & $\begin{array}{l}N=25(92 \% \text { Ž }) \\
M_{\text {star. }}=50,1 \text { let. }\end{array}$ & NEO PI-R & $\begin{array}{l}\text { Spremembe osebnostnih } \\
\text { lastnostnih, dosežene s pomočjo } \\
\text { 10-tedenskega treninga } \\
\text { namernih sprememb, so se } \\
\text { ohranile tudi po štirih letih. }\end{array}$ \\
\hline $\begin{array}{l}\text { Massey- } \\
\text { Abernathy } \\
\text { in Robinson } \\
\text { (2019) }\end{array}$ & $\begin{array}{l}\text { Preučiti učinkovitost } \\
\text { treninga vedenjske } \\
\text { aktivacije na spremembo } \\
\text { vestnosti ter usmerjanja na } \\
\text { spremembo velikih pet. }\end{array}$ & $\begin{array}{l}\text { Študija } 1: N=27(81 \% \check{Z}), \\
M_{\text {star. }}=33 \text { let. } \\
\text { Studija } 2: N=116(72 \% \check{Z}), \\
M_{\text {star. }}=22 \text { let. }\end{array}$ & $\begin{array}{l}\text { Profil vestnosti M- } \\
\text { CBS, RAND-36, Big } \\
\text { Five - IPIP }\end{array}$ & $\begin{array}{l}\text { Po 5-tedenskem treningu } \\
\text { vedenjske aktivacije je prišlo } \\
\text { do povišanja vestnosti, po } \\
\text { 12-tedenskem usmerjanju pa } \\
\text { do sprememb v štirih od petih } \\
\text { temeljni dimenzij osebnosti. } \\
\text { Spremembe so se povezovale } \\
\text { z višjim blagostanjem in } \\
\text { subjektivno oceno zdravja. }\end{array}$ \\
\hline $\begin{array}{l}\text { Miller idr. } \\
(2019)\end{array}$ & $\begin{array}{l}\text { Oceniti pojavnost in } \\
\text { pogostost ciljev za } \\
\text { spremembo osebnosti v } \\
\text { okviru posameznikovih } \\
\text { splošnih življenjskih ciljev. }\end{array}$ & $\begin{array}{l}\text { Vzorec } 1: N=1339 \\
(64 \% \check{Z}), M_{\text {star. }}=18,9 \text { let. } \\
\text { Vzorec } 2: N=447 \\
(61 \% \check{Z}), M_{\text {star. }}=19,2 \text { let. }\end{array}$ & $\begin{array}{l}\text { BFI, BFI-2, odprto } \\
\text { vprašanje o osebnih } \\
\text { ciljih }\end{array}$ & $\begin{array}{l}\text { Cilji za spremembo osebnosti } \\
\text { so v kontekstu življenjskih } \\
\text { ciljev pogosti. Večina } \\
\text { udeležencev je navedla vsaj } \\
\text { en cilj za spremembo svojih } \\
\text { osebnostnih lastnosti. }\end{array}$ \\
\hline $\begin{array}{l}\text { Hudson idr. } \\
\text { (2019a) }\end{array}$ & $\begin{array}{l}\text { Preučiti aktivno vlogo } \\
\text { posameznika pri doseganju } \\
\text { želenih sprememb } \\
\text { osebnosti. }\end{array}$ & $\begin{array}{l}\text { Vzdolžna raziskava: } \\
N=377 \text { (udeleženci, ki so } \\
\text { sodelovali pri vsaj eni od } \\
15 \text { meritev z enotedenskim } \\
\text { razmikom) }\end{array}$ & BFI-2 & $\begin{array}{l}\text { Za dejansko spremembo samo } \\
\text { želja ni dovolj, ampak si mora } \\
\text { posameznik zanjo aktivno } \\
\text { prizadevati s spremembami } \\
\text { v vedenju, mišljenju in } \\
\text { čustvovanju. }\end{array}$ \\
\hline $\begin{array}{l}\text { Hudson idr. } \\
\text { (2019b) }\end{array}$ & $\begin{array}{l}\text { Preučiti, kako natančno } \\
\text { posamezniki zaznavajo } \\
\text { dejansko spremembo } \\
\text { svojih osebnostnih } \\
\text { lastnostih v obdobju štirih } \\
\text { mesecev. }\end{array}$ & $\begin{array}{l}\text { Vzdolžna raziskava: } \\
N=146 \text { (udeleženci, ki so } \\
\text { sodelovali pri vsaj eni od } \\
16 \text { meritev z enotedenskim } \\
\text { razmikom) }\end{array}$ & $\begin{array}{l}\text { BFI-2, C-BFI2, TIPI, } \\
\text { SWLS, samoocena } \\
\text { zaznane spremembe v } \\
\text { osebnostnih lastnostih }\end{array}$ & $\begin{array}{l}\text { Ujemanje med zaznano } \\
\text { in dejansko spremembo v } \\
\text { osebnosti je zmerno. Tako } \\
\text { dejanska kot samozaznana } \\
\text { sprememba neodvisno } \\
\text { napovedujeta blagostanje. }\end{array}$ \\
\hline $\begin{array}{l}\text { Asadi idr. } \\
(2020)\end{array}$ & $\begin{array}{l}\text { Ugotoviti, ali cilji za } \\
\text { spremembo osebnosti } \\
\text { napovedujejo dejanske } \\
\text { spremembe po enem } \\
\text { letu (ponovitev študije } \\
\text { Robinsona idr. (2015) na } \\
\text { iranskem vzorcu). }\end{array}$ & $\begin{array}{l}N=160(62 \% \check{Z}) \\
M_{\text {star. }}=21,1 \text { let. }\end{array}$ & $\begin{array}{l}\text { BF-TGI, BFI, odprto } \\
\text { vprašanje o načrtu } \\
\text { za spremembo } \\
\text { osebnostnih lastnosti }\end{array}$ & $\begin{array}{l}\text { Cilji za spremembo velikih pet } \\
\text { so po enem letu napovedovali } \\
\text { le spremembo odprtosti za } \\
\text { izkušnje. }\end{array}$ \\
\hline $\begin{array}{l}\text { Baranski idr. } \\
(2020)\end{array}$ & $\begin{array}{l}\text { Raziskati povezavo } \\
\text { motivov in zaznav } \\
\text { namernih sprememb } \\
\text { osebnosti z dejanskimi } \\
\text { spremembami po enem letu } \\
\text { oz. šestih mesecih. }\end{array}$ & $\begin{array}{l}\text { Kvalitativna raziskava: } \\
\text { Vzorec } 1: N=530 \\
(44 \% \check{Z}), M_{\text {star. }}=41,5 \text { let. } \\
\text { Vzorec } 2: N=361 \\
(70 \% Z ̌), M_{\text {star. }}=20,5 \text { let. }\end{array}$ & $\begin{array}{l}\text { BFI, odprta vprašanja } \\
\text { o ciljih za spremembo } \\
\text { in doseženih } \\
\text { spremembah osebnosti }\end{array}$ & $\begin{array}{l}\text { Cilji za spremembo osebnosti } \\
\text { se večinoma niso povezovali } \\
\text { z dejanskimi spremembami. } \\
\text { Zmožnost zaznavanja dejanskih } \\
\text { sprememb je bila omejena. }\end{array}$ \\
\hline
\end{tabular}




\begin{tabular}{|c|c|c|c|c|}
\hline $\begin{array}{l}\text { Hudson idr. } \\
(2020)\end{array}$ & $\begin{array}{l}\text { Na velikem vzorcu } \\
\text { udeležencev preveriti, ali } \\
\text { cilji za spremembo osebnosti } \\
\text { napovedujejo dejansko } \\
\text { spremembo v želeni smeri } \\
\text { po štirih mesecih. }\end{array}$ & $\begin{array}{l}\text { Megaanaliza: } \\
N=2238(71 \% \check{\text { Z }}), \\
M_{\text {star. }}=20,3 \text { let. }\end{array}$ & $\begin{array}{l}\text { BFI, BFI-2, IPIP-120, } \\
\text { C-BFI, C-BFI2, } \\
\text { C-IPIP-120 }\end{array}$ & $\begin{array}{l}\text { Cilji za spremembo osebnosti } \\
\text { napovedujejo predvideno } \\
\text { zvišanje na vseh petih temeljnih } \\
\text { osebnostnih lastnosti v obdobju } \\
\text { štirih mesecev. }\end{array}$ \\
\hline
\end{tabular}

Opomba. $N=$ število udeležencev, $\check{Z}=$ ženski spol, $M_{\text {star. }}=$ povprečna starost udeležencev.

prilagoditvijo svojih ciljev za spremembo (Back idr., 2011). Poleg tega naj bi bile bolj natančne samoocene, torej take, ki se ujemajo z ocenami drugih, pomembne za postavljanje realističnih ciljev za spremembo in za njihovo doseganje (London in Smither, 1995).

Raziskave so pokazale tudi, da se cilji za spremembo posameznih osebnostnih lastnosti povezujejo z nezadovoljstvom na različnih življenjskih področjih in z negativno emocionalnostjo (Hudson in Fraley, 2016a; Hudson in Roberts, 2014). Cilji za spremembo ne napovedujejo nujno upada $\mathrm{v}$ psihičnem blagostanju skozi čas (kar bi bilo pričakovati ob ponavljajočih se neuspešnih poskusih spremembe; Polivy in Herman, 2002), ampak je za tiste, ki uspejo doseči želeno spremembo, značilen porast v blagostanju (Hudson in Fraley, 2016a). Nezadovoljstvo lahko torej povzroči pojav ciljev za spremembo osebnosti, uspešna sprememba pa lahko zmanjša nezadovoljstvo in vodi $\mathrm{k}$ izboljšanju blagostanja.

Dosedanje raziskave torej konsistentno kažejo, da si velika večina ljudi želi spremeniti nekatere osebnostne lastnosti, predvsem tiste, ki so manj socialno zaželene in so izvor njihovega nezadovoljstva na različnih življenjskih področjih. S spremembo skušajo zmanjšati svoje nezadovoljstvo oziroma izboljšati svoje počutje. Cilji za spremembo so nekoliko večji in pogostejši pri mladih odraslih in jih lahko povežemo $s$ procesom zorenja, vendar pa si sprememb želijo tudi starejši odrasli.

\section{Ali lahko namerno spremenimo svoje osebnostne lastnosti?}

Ali lahko želja spremeniti svoje osebnostne lastnosti sčasoma dejansko privede do spremembe v želeni smeri? Hudson in Fraley $(2015,2016 a)$ sta izvedla tri intenzivne vzdolžne študije, ki so pokazale, da cilji za spremembo osebnostnih lastnosti napovedujejo spremembo v želeni smeri v obdobju 16 tednov. Pri tistih, ki so na primer želeli povečati svojo ekstravertnost, je $\mathrm{v}$ času študije prišlo do hitrejšega porasta ekstravertnosti v primerjavi s tistimi, ki si te spremembe niso želeli (Hudson in Fraley, 2015).

Pozneje sta ista avtorja s sodelavci (2020) izvedla megaanalizo z vsemi vzdolžnimi podatki iz svojih laboratorijev (tistimi, ki so že bili vključeni $\mathrm{v}$ predhodno objavljenih študijah (Hudson in Fraley, 2015, 2016a), in novejšimi, še ne objavljenimi podatki). Megaanaliza je statistična tehnika za kombiniranje podatkov preko več študij, pri kateri je enota analize vsak posameznik in ne posamezna študija, kot pri metaanalizi (Schimmack, 2012). Na vzorcu preko 2200 mladih odraslih so ugotovili, da cilji za spremembo osebnosti napovedujejo dejansko spremembo $\mathrm{v}$ želeni smeri. Visoki cilji za spremembo nevroticizma in ekstravertnosti (tj. en standardni odklon nad povprečjem) so napovedovali za 0,16 standardnega odklona večjo spremembo v teh osebnostnih lastnostih v obdobju 16 tednov v primerjavi s povprečnimi cilji za spremembo teh lastnosti. Čeprav so bile ugotovljene velikosti učinkov namernih sprememb razmeroma majhne, so primerljive s povprečno rastjo osebnostnih lastnosti pri mladih odraslih v obdobju dveh let (npr. rezultati metaanalize so pokazali, da se pri 18- do 22-letnikih v obdobju dveh let čustvena stabilnost poveča za 0,12 standardnega odklona; Roberts idr., 2006).

Nekoliko drugačne so ugotovitve Robinsona in sodelavcev (2015), ki prav tako na vzorcu študentov niso potrdili povezave med cilji za spremembo in dejanskimi samoocenjenimi spremembami osebnostnih lastnostih v obdobju enega leta oziroma so pri nekaterih lastnostih odkrili celo spremembo $\mathrm{v}$ obratni smeri od pričakovane. $\mathrm{V}$ nedavni ponovitveni študiji med iranskimi študenti so avtorji z enako metodo prišli do podobnih ugotovitev (Asadi idr., 2020). Poleg uporabe drugačnega inštrumenta za merjenje ciljev za spremembo (BF-TGI), so avtorji teh študij spremembe preučevali $\mathrm{v}$ daljšem časovnem obdobju $\mathrm{v}$ primerjavi s študijami iz Hudsonovega laboratorija in meritve izvedli le v dveh časovnih točkah. Hudson in kolegi (2020) pa so udeležence intenzivno spremljali skozi en študijski semester in $v$ povprečju izvedli enajst meritev na udeleženca. S ponovljenimi meritvami ciljev za spremembo (in intervencijami) so ohranjali želeno spremembo v mislih udeležencev in tako spodbudili učinkovitejše zasledovanje ciljev. Vzrok za neenotne ugotovitve študij so torej lahko tako metodološke razlike kot možna kratkotrajna ali ciklična narava namernih sprememb osebnosti (Hudson idr., 2020).

Drugačno, kvalitativno metodologijo so v svoji raziskavi uporabili E. Baranski in sodelavci (2020), ki so preučevali povezavo motivov in zaznav namernih osebnostnih sprememb z dejanskimi spremembami osebnostnih lastnostih po enem letu oziroma šestih mesecih. Podobno kot Robinson in kolegi (2015) udeležencev niso opominjali na njihove cilje ali uporabili kake druge tehnike spodbujanja sprememb, ampak so le primerjali razvoj osebnostnih lastnosti pri tistih, ki so ali niso izrazili želje za njihovo spremembo. Ugotovitve so bile podobne kot v raziskavi Robinsona in sodelavcev (2015). Do želene spremembe osebnostnih lastnostih pri udeležencih ni prišlo ali pa je bila sprememba celo obratna od želene. Te ugotovitve nakazujejo na težavnost doseganja želenih osebnostnih sprememb brez zunanjega vodstva.

$\mathrm{V}$ zvezi $\mathrm{z}$ doseganjem namernih sprememb osebnosti omenimo še raziskavo Hudsona in sodelavcev (2019b), ki je pokazala zmerno ujemanje med dejansko spremembo samoocenjenih osebnostnih lastnostih in zaznavo posameznikov, kako so se spremenili v obdobju štirih mesecev. 
Skoraj dve petini udeležencev sta zaznali spremembo $\mathrm{v}$ obratni smeri, kot so jo kazale razlike v samoocenah, podanih ob obeh merjenjih. To pomeni, da se posamezniki lahko spreminjajo v smeri zastavljenih ciljev tudi, če teh sprememb ne zaznavajo. Podobno so tudi E. Baranski in sodelavci (2020) v kvalitativni študiji ugotovili omejeno zmožnost udeležencev, da bi točno zaznali spremembe svoje osebnosti po šestih mesecih.

Če povzamemo, rezultati dosedanjih raziskav glede doseganja namernih sprememb osebnosti niso povsem enotni. Dejanske spremembe osebnostnih lastnostih so se pokazale le $\mathrm{v}$ raziskavah, $\mathrm{v}$ katerih so udeležence nekaj mesecev intenzivno spremljali skozi proces namernega spreminjanja njihovih osebnostnih lastnosti, kar kaže na pomen zunanjega vodstva za uspešno doseganje sprememb. Odprto ostaja vprašanje, kako trajna je narava teh sprememb.

\section{Kateri so dejavniki namernih sprememb osebnosti ter ciljev za spremembo?}

Nekateri avtorji so se posebej usmerili k preučevanju dejavnikov, ki privedejo do namernih, samoregulativnih osebnostnih sprememb. Prevladujoča predpostavka je, da ti procesi potekajo "od spodaj navzgor", ne ker spremembe v obratni smeri ne bi bile mogoče, ampak ker proces spreminjanja "od zgoraj navzdol" zahteva več časa in podporo intenzivnejših intervencij, na primer psihoterapije, za spreminjanje celotnih vzorcev vedenja, mišljenja in čustvovanja (Allemand in Flückiger, 2017).

M. Hennecke in sodelavci (2014) so izpostavili tri ključne pogoje, preko katerih lahko s samoregulacijo dosežemo želeno spremembo osebnosti. Poleg želje po spremembi izkušenj in vedenj je drugi pogoj izvedljivost novih izkušenj in vedenj ter sposobnost izvajati želene spremembe. Zadnji, tretji pogoj pa je, da morajo želene spremembe postati nekaj vsakdanjega, da se lahko ohranijo. Za spremembo torej ni dovolj le želja, da bi na primer postali bolj vestni, ampak se mora ta želja manifestirati v konkretnih osebnostnih stanjih višje vestnosti, na primer preko rednega preverjanja seznama obveznosti in spremljanja napredka pri doseganju ciljev. Sčasoma lahko spremenjene navade privedejo do spremembe splošne samopodobe posameznika, katere del so tudi njegove osebnostne lastnosti.

Allemand in Flückiger (2017) navajata štiri splošne mehanizme oziroma dejavnike, ki lahko skozi (neklinično) intervencijo privedejo do namernih osebnostnih sprememb. Najprej mora posameznik prepoznati razlike med trenutnimi in želenimi osebnostnimi lastnostmi. Naslednji dejavnik je aktivacija močnih točk in virov, ki so lahko povezani $z$ znanjem, spretnostmi, motiviranostjo za spremembe in oporo pomembnih drugih. Tretji dejavnik se nanaša na prepoznavo in spreminjanje prepričanj, pričakovanj in motivov $\mathrm{V} \mathrm{Z}$ zvezi s spremembo (npr. prepričanje o stabilnosti nasproti spremenljivosti osebnostnih lastnosti). Zadnji dejavnik pa je prepoznava in izvedba novih vedenj.

$\mathrm{Za}$ razumevanje procesa, ki privede do namernih sprememb osebnosti, so zanimive tudi ugotovitve kvalitativne študije, v kateri so med drugim preučevali strategije, ki jih ljudje uporabljajo, da bi dosegli želeno osebnostno spremembo (Baranski idr., 2017). Želja po višji ekstravertnosti in vestnosti se je pozitivno povezovala $\mathrm{z}$ uporabo vedenjskih strategij, želja po višji sprejemljivosti in čustveni stabilnosti pa $\mathrm{z}$ uporabo kognitivnih strategij. Posamezniki, ki so na primer želeli postati bolj ekstravertni, so si prizadevali vesti se drugače (npr. govorno nastopanje pred drugimi, sodelovanje z drugimi, pogovarjanje z več ljudmi), medtem ko so si tisti, ki so imeli željo zvišati svojo sprejemljivost, prizadevali razmišljati drugače (npr. večja pozornost na lastno kritičnost ali na čustva drugih ljudi).

Pri doseganju namernih osebnostnih sprememb ima pomembno vlogo načrtovanje aktivnosti (Gollwitzer in Brandstätter, 1997). Robinson in sodelavci (2015) so med drugim ugotovili, da večina mladih odraslih s cilji za spremembo osebnosti oblikuje splošen ali specifičen načrt, kako bo svoj cilj dosegla. Najpogosteje so bili z načrti povezani cilji za spremembo ekstravertnosti in sprejemljvosti, najbolj specifični pa so bili načrti za spremembo vestnosti in ekstravernosti. Vendar pa avtorji v tej raziskavi niso odkrili pozitivne povezave med cilji in načrti za spremembo in dejansko spremembo po enem letu. $\mathrm{V}$ raziskavi Hudsona in Fraleya (2015) se je izkazalo, da lahko dejansko doseganje želenih sprememb spodbudi predvsem oblikovanje in sledenje specifičnim izvedbenim načrtom za doseganje zastavljenih ciljev.

Raziskave so preučevale tudi različne dejavnike, s katerimi se povezujejo cilji za spremembo osebnosti. Spremembe si bolj prizadevajo doseči tisti posamezniki, ki so manj optimistični, bolj nezadovoljni s sabo in svojim življenjem, bolj osamljeni in imajo manjši občutek nadzora nad situacijo (Quintus idr., 2017). Obstoj ciljev za spremembo se povezuje tudi $\mathrm{z}$ večjo razliko med posameznikovo idealno in dejansko oceno osebnostnih lastnosti, poleg tega pa se cilji za spremembo vestnosti in nevroticizma povezujejo $\mathrm{z}$ manjšim občutkom avtentičnosti in z nižjim sprejemanjem sebe (Robinson idr., 2015). Željo po spremembi krepijo tudi nekatere osebnostne lastnosti, saj imajo za spremembo motivirani posamezniki višjo odprtost in nevroticizem $\mathrm{v}$ primerjavi $\mathrm{z}$ normativno populacijo (Allan idr., 2014). Bolj odprti se bolj zanimajo za nove ideje, pripravljeni so preizkusiti drugačna vedenja in tvegati. Visoko nevroticistični posamezniki pa pogosto doživljajo negativna čustva, povezana $\mathrm{z}$ različnimi negativni izidi, kar jih lahko spodbudi k spremembi.

Skladno s predpostavkami širših modelov osebnostnih sprememb (Geukes idr., 2018; Wrzus in Roberts, 2017) do namernih, samoregulativnih sprememb verjetno torej prihaja "od spodaj navzgor" preko spreminjanja in utrjevanja novih vzorcev vedenja, mišljenja ali čustvovanja v različnih situacijah. Strategije, ki jih ljudje uporabljajo, da bi dosegli osebnostne spremembe, se lahko razlikujejo glede na lastnost, ki jo želijo spremeniti. Spremeniti skušajo lahko bodisi svoje vedenje bodisi razmišljanje v konkretni situaciji. Za uspešno doseganje teh sprememb naj bi bilo pomembno oblikovanje specifičnih načrtov, ki posamezniku pomagajo, da se $\mathrm{v}$ konkretni situaciji odzove v skladu s cilji. Za posameznike, ki se želijo spremeniti, so značilne nekatere tipične osebnostne lastnosti. 


\section{Katere so in kako učinkovite so intervencije za} namerno spremembo osebnostnih lastnosti?

Že pretekle študije so pokazale, da so lahko nekateri treningi in neklinične intervencije (trening čuječnosti, kognitivni trening idr.) koristni pri spreminjanju osebnostnih lastnosti (Jackson idr., 2012; Krasner idr., 2009). V zadnjih letih pa je bilo razvitih in preliminarno preizkušenih tudi več intervencij, namenjenih prav spodbujanju namernih sprememb osebnosti.

Hudson in Fraley $(2015,2016 a)$ sta v svojih prvih približno štirimesečnih intenzivnih vzdolžnih študijah preučevala učinkovitost intervencij, ki so vključevale razvoj veščin načrtovanja (Gollowitzer in Brandstätter, 1997) in oblikovanja jasnih in konkretnih čustvenih, kognitivnih in vedenjskih izvedbenih načrtov (tj. "če-potem” načrti) za dosego ciljev za spremembo osebnosti. Pri udeležencih je po štirih mesecih prišlo do značilne spremembe osebnostnih lastnosti v želeni smeri. V poznejši študiji so Hudson in sodelavci (2019a) oblikovali in preizkusili učinkovitost intervencije, usmerjene $\mathrm{k}$ spodbujanju posameznikove aktivne vloge pri doseganju želenih osebnostnih sprememb. Udeleženci so si morali izbrati in izpolnjevati tedenske izzive v obliki konkretnih, specifičnih vedenj, tipičnih za posameznike z želenimi osebnostnimi lastnostmi. Raziskava je pokazala, da samo želja po spremembi (tj. odločitev za tedenske izzive brez dejanskega izpolnjevanja teh izzivov) za spremembo ni dovolj, ampak si mora posameznik zanjo aktivno prizadevati s spremembami v svojem vedenju, mišljenju in čustvovanju.

Martin je s sodelavci (2012, 2014a) predstavil koncept večstopenjskega usmerjanja (angl. coaching) oziroma treninga namernih sprememb osebnosti, ki prav tako vključuje identifikacijo ciljev za spremembo in oblikovanje načrta za njihovo doseganje. Glavni koraki treninga zajemajo oceno osebnosti, vrednot in samopodobe posameznika ter razlike med njegovim trenutnim in idealnim jazom, izbiro ciljev za spremembo osebnosti, oceno stališč do spremembe, izdelavo in izvedbo načrta treninga glede na zastavljene cilje ter ponovno oceno osebnosti in napredka pri doseganju ciljev. Preliminarna evalvacijska študija desettedenskega strukturiranega programa na manjšem vzorcu udeležencev in s kontrolno skupino je pokazala značilne pozitivne učinke treninga na želeno spremembo osebnostnih lastnostih. Pri nekaterih osebnostnih lastnostih so se spremembe obdržale še tri mesece (Allan idr., 2018; Martin idr., 2014b) oziroma štiri leta po zaključku treninga (Martin-Allan idr., 2019). S kvalitativno metodo induktivne tematske analize so Martin in sodelavci (2015) preučili tudi subjektivno izkušnjo udeležencev $\mathrm{z}$ desettedenskim treningom namernih sprememb osebnosti. V odgovorih udeležencev na polstrukturiran intervju so identificirali štiri ključne teme, in sicer (1) spodbujanje samorefleksije in večjega samozavedanja; (2) spodbujanje avtentičnosti in delovanja v skladu z vrednotami; (3) oprijemljive in praktične koristi treninga; in (4) večini se je zdel trening prijeten, pozitiven in koristen.

Nekateri avtorji so pri oblikovanju intervencij za namerno spreminjanje osebnosti uporabili tehniko vedenjske aktivacije (Lejuez idr., 2011). Udeleženci treninga za krepitev vestnosti (Magidson idr., 2014) morajo spremljati svoje vsakodnevne aktivnosti in nato opredeliti, načrtovati in vztrajno izvajati alternativne aktivnosti, ki se ujemajo $z$ njihovimi vrednotami oziroma cilji za spremembo. Trening je bil preliminarno preizkušen s študijo primera, ki je pokazala, da se je vedenje 45-letnika, odvisnega od opiatov, po dvanajsttedenski intervenciji, usmerjeni k usvajanju bolj pozitivnih in rednih vedenjskih vzorcev na različnih življenjskih področjih, močno izboljšalo v smeri večje vestnosti. Podobno sta tudi A. Massey-Abernathy in Robinson (2019) v dveh pilotnih študijah ugotovila učinkovitost pettedenskega treninga vedenjske aktivacije na spremembo facet vestnosti ter dvanajsttedenskega usmerjanja ( $\mathrm{z}$ bolj odprtim in manj strukturiranim pristopom kot $\mathrm{v}$ prej opisanih študijah Martina in kolegov) na spremembo facet štirih izmed velikih pet osebnostnih lastnosti. Spremembe so se pri udeležencih v obeh študijah povezovale tudi z okrepljenim čustvenim blagostanjem in subjektivno oceno fizičnega zdravja (glej tudi Chapman idr., 2014).

Za usmerjanje pri namernem spreminjanju osebnosti bo morda $\mathrm{v}$ prihodnje mogoče uporabiti tudi aplikacije na pametnih telefonih. Aplikacija PEACH (PErsonality coACH) je namenjena intervenciji desettedenskega usmerjanja za namerno spremembo osebnosti (Stieger idr., 2018). Intervencija, ki za podporo posamezniku pri doseganju ciljev uporablja t. i. klepetalnega robota (angl. chatbot), vključuje oblikovanje individualiziranih ciljev, psihoedukacijo, naloge vedenjske aktivacije, samorefleksijo, aktivacijo osebnih virov in individualizirano povratno informacijo o napredku. Stieger in sodelavci (2018) so predstavili protokol študije, s katero nameravajo preizkusiti učinkovitost aplikacije oziroma desettedenske intervencije pri doseganju namernih sprememb osebnosti.

Vsem intervencijam za namerno spreminjanje osebnosti, opisanim v tem poglavju, je skupno, da se sprememb osebnosti lotevajo preko spreminjanja vedenja, mišljenja in čustvovanja $\mathrm{v}$ konkretnih situacijah in posameznikom pomagajo pri utrjevanju novih vedenjskih oblik vse do stopnje, ko postanejo avtomatizirane in se odrazijo v trajni spremembi osebnostnih lastnosti. Začetne raziskave na manjših vzorcih in skozi krajša časovna obdobja kažejo na potencial teh intervencij pri spodbujanju doseganja želenih sprememb osebnosti.

\section{Kritično ovrednotenje pregledanih študij in ideje za prihodnje raziskave}

Prve raziskave s področja namernih sprememb osebnosti kažejo, da želi večina posameznikov spremeniti nekatere svoje osebnostne lastnosti in da jih lahko tudi dejansko spremenijo, pri čemer so jim lahko $\mathrm{v}$ pomoč različne neklinične intervencije. Ker so raziskave namernih sprememb osebnosti še v povojih, ostajajo mnoga vprašanja še nenaslovljena, veliko pa je tudi možnosti za izboljšave dosedanjih raziskav.

Prva pomembna pomanjkljivost pregledanih raziskav je zanašanje na metodo samoocenjevanja. Čeprav imajo posamezniki preko introspekcije boljši vpogled vase, kot ga imajo zunanji opazovalci, ima samoocenjevanje tudi nekatere omejitve, kot je na primer pristranskost zaradi socialno zaželenega odgovarjanja. Poleg tega lahko udeleženec poroča o želeni spremembi osebnosti zaradi močne motiviranosti za 
spremembo, čeprav do dejanske spremembe ni prišlo (Paulhus in Vazire, 2007). V prihodnje bi veljalo poleg samoocen osebnostnih lastnosti, ciljev za spremembo in doseženih sprememb $\mathrm{v}$ raziskave vključiti tudi poročila opazovalcev ali pomembnih drugih, ki bi ocenjevali osebnostne lastnosti in vedenja posameznikov skozi čas (glej Quintus idr., 2017). Prav tako bi lahko samoocenjevalne vprašalnike smiselno dopolnili $\mathrm{z}$ metodo vzorčenja izkušenj (angl. experience sampling method - ESM; Csikszentmihalyi in Larson, 1987), ki omogoča bolj direktno samoocenjevanje vedenja, mišljenja in čutenja in s tem verjetno tudi večjo objektivnost in natančnost merjenja.

Druga pomanjkljivost, ki jo pogosto izpostavljajo tudi avtorji sami, je uporaba neraznolikih pripomočkov oziroma metod za merjenje osebnostnih lastnosti in ciljev za njihovo spremembo. $Z$ uporabo različnih metod in inštrumentov bi lahko prepoznali in preprečili pristranskost udeležencev pri poročanju o njihovih ciljih in doseganju želenih sprememb osebnostnih lastnostih ter presegli pomanjkljivosti posameznih metod merjenja (glej Baranski idr., 2017; Hudson in Fraley, 2015).

Tretja pomanjkljivost je majhnost in precejšnja homogenost vzorcev. Omeniti moramo tudi, da v nekatere intervencijske študije kontrolna skupina ni bila vključena (npr. Hudson in Fraley, 2016a; Hudson in Roberts, 2014). Večina raziskav je bila izvedena na vzorcih ene starostne skupine (npr. Hudson in Fraley, 2015; Hudson in Fraley 2016a; Hudson in Roberts, 2014), večinoma mladih odraslih iz anglosaksonskega okolja (za izjemo glej Asadi idr., 2020; Robinson idr., 2015). Zaradi teh pomanjkljivosti je posplošljivost rezultatov manjša. $\mathrm{V}$ prihodnje bi bilo smiselno $\mathrm{v}$ raziskave namernih sprememb osebnosti zajeti večje in demografsko bolj heterogene vzorce udeležencev iz različnih kulturno jezikovnih okolij, v študije intervencij pa vključiti kontrolno skupino.

Medtem ko so nekatere pretekle raziskave preučevale spremembe na vseh dimenzijah modela velikih pet, so se druge osredotočile le na spremembe v eni temeljni dimenziji osebnosti (npr. Magidson idr., 2014). V prihodnjih raziskavah bi veljalo podrobneje preučiti, kakšna je dinamika in narava sprememb posameznih temeljnih dimenzij osebnosti in njihovih facet, saj bi na tak način dobili širši in natančnejši vpogled v spreminjanje osebnostne strukture posameznika. $\mathrm{S}$ primerjavo različnih intervencij bi lahko ugotovili tudi, katere so bolj ali manj primerne za spodbujanje sprememb v določenih osebnostnih lastnostih.

Zanimivo področje za prihodnje raziskave je tudi povezanost različnih kognitivnih procesov $\mathrm{z}$ namernim spreminjanjem osebnostnih lastnosti. Izvršilni nadzor bi lahko predstavljal enega izmed osnovnih mehanizmov namernih osebnostnih sprememb. Gre za funkcijo kognitivnega sistema, ki posameznikom omogoča, da regulirajo svoje vedenje glede na cilje oziroma načrte, ki jih imajo. Ključen je pri vsakodnevnem vedenju, saj se $\mathrm{z}$ njegovo pomočjo posamezniki uprejo trenutnim skušnjavam in navadam, da lahko zasledujejo nek drug dolgoročen cilj (Verbruggen idr., 2014). To posameznikom omogoča, da utrjene in avtomatične vzorce vedenja, mišljenja in čustvovanja zamenjajo $\mathrm{z}$ novimi, značilnimi za lastnosti, ki si jih pri sebi želijo, kar naj bi sčasoma privedlo do trajnih osebnostnih sprememb
(Allemand in Flückiger, 2017). Zdi se, da je za prilagojeno vedenje med izvršilnimi funkcijami še posebej pomemben inhibitorni nadzor (Gligorović in Buha, 2013). V povezavi $\mathrm{z}$ osebnostnimi lastnostmi so to vrsto nadzora že omenjali nekateri avtorji, na primer Logan in sodelavci (1997), ki so v eksperimentalni študiji ugotovili, da se višja impulzivnost (faceta ekstravertnosti po Eysencku) povezuje s slabšo inhibicijo odzivov.

Zelo pomembno je, da prihodnje raziskave preučijo, kakšna je stabilnost namernih osebnostnih sprememb oziroma kako dolgo se spremembe ohranijo. Nekaj dosedanjih raziskav je preučevalo stabilnost sprememb skozi krajša časovna obdobja, večinoma nekaj mesecev, daljša obdobja spremljanja udeležencev pa ostajajo izziv za prihodnje raziskave. Prav tako bi bilo zanimivo preveriti, ali se določene osebnostne lastnosti lažje oziroma hitreje spreminjajo v odvisnosti od demografskih značilnosti posameznika (npr. spol, starost, izobrazba), ter raziskati, ali so možne ponovne spremembe osebnostnih lastnostih, ki so že bile namerno spremenjene.

Nenazadnje bi v prihodnjih raziskavah veljajo natančneje preučiti vlogo motivacije za namerne spremembe osebnosti, na primer ali želijo posamezniki svoje osebnostne lastnosti spremeniti zaradi lastnega interesa, ker menijo, da bi bilo to zanje dobro (npr. posameznik veliko časa preživlja sam in meni, da je $\mathrm{v}$ družbi preveč zadržan, zato želi postati bolj ekstraverten), ali pa želijo s spremembo ugoditi pomembnim drugim (npr. posameznik želi biti bolj ektraverten, ker mu drugi govorijo, da se prepogosto drži sam zase). Motivacijo za spremembo oziroma poročanje o spremembi bi lahko predstavljala tudi nagrada, ki so jo v nekaterih raziskavah udeleženci prejeli za sodelovanje. Razlike v motivaciji za spremembo bi lahko imele učinek na velikost in stabilnost dejanske spremembe. Quintus in sodelavci (2017) so na primer ugotovili, da si posamezniki bolj prizadevajo spremeniti svojo ekstravertnost, vestnost in sprejemljivost, kadar te osebnostne lastnosti pri njih drugi ocenijo kot nizke.

\section{Zaključek}

Namerne spremembe osebnosti predstavljajo razmeroma novo in malo raziskano področje znotraj psihologije osebnosti, čeprav ideja, da je mogoče osebnost spremeniti s svojim lastnim prizadevanjem, v psihologiji ni nova (Kiecolt, 1994), močno pa je prisotna tudi v širši družbi, kjer sta delo na sebi in samopomoč vse bolj del popularne kulture. V prispevku smo sistematično pregledali znanstveno literaturo o namernih spremembah osebnosti, ki se kot samostojna tema in osrednji raziskovalni problem pojavljajo šele $\mathrm{v}$ zadnjih letih. Glavne ugotovitve kažejo, da si ljudje ne le želijo spremeniti nekatere svoje osebnostne lastnosti, ampak lahko z lastnim prizadevanjem ter specifičnimi cilji in načrtom to tudi dejansko storijo. Različni avtorji razumejo namerne spremembe osebnosti kot proces, ki poteka "od spodaj navzgor", njegova ključna sestavina pa so osebnostna stanja. Glavni mehanizem osebnostne spremembe torej predstavlja sprememba aktualnega vedenja, mišljenja in čustvovanja vse do ravni avtomatizma. Razvitih in preliminarno preizkušenih je bilo več intervencij, ki spodbujajo spreminjanje osebnostnih lastnosti v želeni smeri. V prispevku smo navedli tudi nekatere ključne pomanjkljivosti dosedanjih študij in 
podali predloge za prihodnje raziskave, ki bi v prvi vrsti morale vključiti večje in bolj heterogene vzorce udeležencev in druge metode merjenja poleg samoocen ter zajeti daljše časovne intervale, v katerih bi preučile dolgoročno stabilnost sprememb.

Znanstveno preučevanje vloge posameznikovega lastnega prizadevanja pri spreminjanju njegovih osebnostnih lastnosti je relevantno tako $\mathrm{z}$ vidika bolj poglobljenega razumevanja dinamike vseživljenjskega osebnostnega razvoja, kot zaradi svoje aplikativne vrednosti. Osebnostne lastnosti se namreč povezujejo z najrazličnejšimi življenjskimi izidi, kot so izobrazba, poklic, dohodek, delovna uspešnosti, kakovost medosebnih odnosov ter psihično in fizično zdravje (Bleidorn idr., 2019), in sicer v enaki ali celo večji meri, kot na primer socialno-ekonomski status, ki velja za široko sprejet dejavnik življenjskega uspeha (Roberts idr., 2007). Sprememba osebnostnih lastnosti v želeni smeri lahko torej pomembno prispeva $\mathrm{k}$ izboljšanju različnih življenjskih izidov in s tem h kakovosti posameznikovega življenja, pa tudi širšega družbenega delovanja.

\section{Opomba avtorjev}

Raziskavo je sofinancirala Javna agencija za raziskovalno dejavnost Republike Slovenije iz državnega proračuna (program P5-0110).

\section{Literatura}

Allan, J. A., Leeson, P. in Martin, L. S. (2014). Who wants to change their personality and what do they want to change? International Coaching Psychology Review, $9(1), 8-21$.

Allan, J., Leeson, P., De Fruyt, F. in Martin, S. (2018). Application of a 10 week coaching program designed to facilitate volitional personality change: Overall effects on personality and the impact of targeting. International Journal of Evidence Based Coaching and Mentoring, 16(1), 80-94.

Allemand, M. in Flückiger, C. (2017). Changing personality traits: Some considerations from psychotherapy processoutcome research for intervention efforts on intentional personality change. Journal of Psychotherapy Integration, 27(4), 476-494.

Allemand, M., Hill, P. L. in Lehmann, R. (2015). Divorce and personality development across middle adulthood. Personal Relationships, 22(1), 122-137.

Allport, G. W. (1961). Pattern and growth in personality. Holt, Reinhart \& Winston.

Asadi, S., Dehaj, H. M. in Robinson, O. (2020). Personality change goals and plans as predictors of longitudinal trait change in young adults: A replication with an Iranian sample. Journal of Research in Personality, 85, 103912.

Back, M. D., Baumert, A., Denissen, J. J. A., Hartung, F. M., Penke, L., Schmukle, S. C., Schönbrodt, F. D., SchröderAbé, M., Vollmann, M., Wagner, J. in Wrzus, C. (2011). PERSOC: A unified framework for understanding the dynamic interplay of personality and social relationships. European Journal of Personality, 25, 90-107.
Baranski, E., Gray, J., Morse, P. in Dunlop, W. (2020). From desire to development? A multi-sample, idiographic examination of volitional personality change. Journal of Research in Personality, 85, 103910-103922.

Baranski, E. N., Morse, P. J. in Dunlop, W. L. (2017). Lay conceptions of volitional personality change: From strategies pursued to stories told. Journal of Personality, 85(3), 285-299.

Bleidorn, W. (2015). What accounts for personality maturation in early adulthood? Current Directions in Psychological Science, 24, 245-252.

Bleidorn, W., Hill, P. L., Back, M. D., Denissen, J. J., Hennecke, M., Hopwood, C. J., Jokela, M., Kandler, C., Lucas, R. E., Luhmann, M., Orth, U., Wagner, J., Wrzus, C., Zimmermann, J. in Roberts, B. (2019). The policy relevance of personality traits. American Psychologist, 74(9), 1056-1067.

Bleidorn, W., Hopwood, C. J. in Lucas, R. E. (2018). Life events and personality trait change. Journal of Personality, 86 , $83-96$.

Bleidorn, W., Kandler, C., Riemann, R., Spinath, F. M. in Angleitner, A. (2009). Patterns and sources of adult personality development: Growth curve analyses of the NEO-PI-R scales in a longitudinal twin study. Journal of Personality and Social Psychology, 97, 142-155.

Briley, D. A. in Tucker-Drob, E. M. (2014). Genetic and environmental continuity in personality development: A meta-analysis. Psychological Bulletin, 140, 1303-1331.

Chapman, B. P., Hampson, S. in Clarkin, J. (2014). Personality-informed interventions for healthy aging: Conclusions from a National Institute on Aging work group. Developmental Psychology, 50(5), 1426-1441.

Cramer, A. O., Van der Sluis, S., Noordhof, A., Wichers, M., Geschwind, N., Aggen, S. H., Kendler, K. S. in Borsboom, D. (2012). Dimensions of normal personality as networks in search of equilibrium: You can't like parties if you don't like people. European Journal of Personality, 26(4), 414-431.

Csikszentmihalyi, M. in Larson, R. (1987). Validity and reliability of the experience-sampling method. Journal of Nervous and Mental Disease, 175(9), 526-536.

Denissen, J. J. A. in Penke, L. (2008). Motivational individual reaction norms underlying the five-factor model of personality: First steps towards a theorybased conceptual framework. Journal of Research in Personality, 42, 1285-1302.

Dunlop, P. D., Telford, A. D. in Morrison, D. L. (2012). Not too little, but not too much: The perceived desirability of responses to personality items. Journal of Research in Personality, 46(1), 8-18.

Fleeson, W. (2001). Toward a structure-and processintegrated view of personality: Traits as density distributions of states. Journal of Personality and Social Psychology, 80(6), 1011-1027.

Geukes, K., van Zalk, M. in Back, M. D. (2018). Understanding personality development: An integrative state process model. International Journal of Behavioral Development, 42(1), 43-51. 
Gligorović, M. in Buha, N. (2013). Inhibitorna kontrola kao činilac problema u ponašanju kod dece sa lakom intelektualnom ometenošću. Specijalna edukacija $i$ rehabilitacija, 12(2), 149-162.

Goldberg, L. R. (1990). An alternative "description of personality": The big five factor structure. Journal of Personality and Social Psychology, 59, 1216-1229.

Gollwitzer, P. M. in Brandstätter, V. (1997). Implementation intentions and effective goal pursuit. Journal of Personality and Social Psychology, 73(1), 186-199.

Hennecke, M., Bleidorn, W., Denissen, J. J. in Wood, D. (2014). A three-part framework for self-regulated personality development across adulthood. European Journal of Personality, 28(3), 289-299.

Higgins, E. T. (1987). Self-discrepancy: A theory relating self and affect. Psychological Review, 94(3), 319-340.

Hudson, N. W., Briley, D. A., Chopik, W. J. in Derringer, J. (2019a). You have to follow through: Attaining behavioral change goals predicts volitional personality change. Journal of Personality \& Social Psychology, 117(4), 839-857.

Hudson, N. W., Derringer, J. in Briley, D. A. (2019b). Do people know how they've changed? A longitudinal investigation of volitional personality change and participants' retrospective perceptions thereof. Journal of Research in Personality, 83, 103879.

Hudson, N. W. in Fraley, R. C. (2015). Volitional personality trait change: Can people choose to change their personality traits? Journal of Personality and Social Psychology, 109(3), 490-507.

Hudson, N. W., in Fraley, R. C. (2016a). Changing for the better? Longitudinal associations between volitional personality change and psychological well-being. Personality and Social Psychology Bulletin, 42(5), 603-615.

Hudson, N. W., in Fraley, R. C. (2016b). Do people's desires to change their personality traits vary with age? An examination of trait change goals across adulthood. Social Psychological and Personality Science, 7(8), 847-856.

Hudson, N. W., Fraley, R. C., Chopik, W. J. in Briley, D. A. (2020). Change goals robustly predict trait growth: A mega-analysis of a dozen intensive longitudinal studies examining volitional change. Social Psychological and Personality Science, 11(6), 723-732.

Hudson, N. W. in Roberts, B. W. (2014). Goals to change personality traits: Concurrent links between personality traits, daily behavior, and goals to change oneself. Journal of Research in Personality, 53, 68-83.

Hudson, N. W., Roberts, B. W. in Lodi-Smith, J. (2012). Personality trait development and social investment in work. Journal of Research in Personality, 46, 334-344.

Jackson, J. J., Hill, P. L., Payne, B. R., Roberts, B. W. in StineMorrow, E. A. (2012). Can an old dog learn (and want to experience) new tricks? Cognitive training increases openness to experience in older adults. Psychology and Aging, 27(2), 286-292.

John, O. P., Donahue, E. M. in Kentle, R. L. (1991). The Big Five Inventory--Versions $4 a$ and 54. University of California, Berkeley, Institute of Personality and Social Research.
Kiecolt, K. J. (1994). Stress and the decision to change oneself: A theoretical model. Social Psychology Quarterly, 57, 49-63.

Krasner, M. S., Epstein, R. M., Beckman, H., Suchman, A. L., Chapman, B., Mooney, C. J. in Quill, T. E. (2009). Association of an educational program in mindful communication with burnout, empathy, and attitudes among primary care physicians. Jama, 302(12), 1284-1293.

Lang, F. R. in Heckhausen, J. (2001). Perceived control over development and subjective well-being: Differential benefits across adulthood. Journal of Personality and Social Psychology, 81, 509-523.

Lehnart, J., Neyer, F. J. in Eccles, J. (2010). Long-term effects of social investment: The case of partnering in young adulthood. Journal of Personality, 78, 639-670.

Lejuez, C. W., Hopko, D. R., Acierno, R., Daughters, S. B. in Pagoto, S. L. (2011). Ten year revision of the brief behavioral activation treatment for depression: Revised treatment manual. Behavior Modification, 35(2), 111-161.

Logan, G. D., Schachar, R. J. in Tannock, R. (1997). Impulsivity and inhibitory control. Psychological Science, 8(1), 60-64.

London, M. in Smither, J. W. (1995). Can multi-source feedback change perceptions of goal accomplishment self-evaluations, and performance-related outcomes? Theory-based applications and directions for research. Personnel Psychology, 48, 803-839.

Lüdtke, O., Roberts, B. W., Trautwein, U. in Nagy, G. (2011). A random walk down university avenue: Life paths, life events, and personality trait change at the transition to university life. Journal of Personality and Social Psychology, 101(3), 620-637.

Magidson, J. F., Roberts, B. W., Collado-Rodriguez, A. in Lejuez, C. W. (2014). Theory-driven intervention for changing personality: Expectancy value theory, behavioral activation, and conscientiousness. Developmental Psychology, 50(5), 1442-1450.

Martin, L. S., Oades, L. G. in Caputi, P. (2012). What is personality change coaching and why is it important? International Coaching Psychology Review, 7(2), 185-193.

Martin, L. S., Oades, L. G. in Caputi, P. (2014a). A stepwise process of intentional personality change coaching. International Coaching Psychology Review, 9(2), 181-195.

Martin, L. S., Oades, L. G. in Caputi, P. (2014b). Intentional personality change coaching: A randomised controlled trial of participant selected personality facet change using the Five-Factor Model of Personality. International Coaching Psychology Review, 9(2), 195-209.

Martin, L. S., Oades, L. G. in Caputi, P. (2015). Clients' experiences of intentional personality change coaching. International Coaching Psychology Review, 10(1), 94-108.

Martin-Allan, J., Leeson, P. in Martin, L. S. (2019). Intentional personality change coaching: A four-year longitudinal study. International Coaching Psychology Review, 14(2), 44-56. 
Massey-Abernathy, A. R. in Robinson, D. N. (2019). Personality promotion: The impact of coaching and behavioral activation on facet level personality change and health outcomes. Current Psychology, 1-12.

McCrae, R. R. in Costa, P. T. (1985). The NEO PI/FFI Personality Inventory manual. Psychological Assessment Resources

McCrae, R. R. in Costa, P. T. (2008). The five-factor theory of personality. V O. P. John, R. W. Robins in L. A. Pervin (ur.), Handbook of personality: Theory and research (3. izd., str. 150-181). Guilford Press.

Miller, T. J., Baranski, E. N., Dunlop, W. L. in Ozer, D. J. (2019). Striving for change: The prevalence and correlates of personality change goals. Journal of Research in Personality, 80, 10-16.

Moher D., Liberati A., Tetzlaff J., Altman D. G. in The PRISMA Group (2009). Preferred reporting items for systematic reviews and meta-analyses: The PRISMA statement. PLoS Medicine, 6(7), 264-269.

Nelis, D., Kotsou, I., Quoidbach, J., Hansenne, M., Weytens, F., Dupuis, P. in Mikolajczak, M. (2011). Increasing emotional competence improves psychological and physical well-being, social relationships, and employability. Emotion, 11(2), 354-366.

Paulhus, D. L. in Vazire, S. (2007). The self-report method. V R. W. Robins, R. C. Fraley in R. F. Krueger (ur.), Handbook of research methods in personality psychology (str. 224 -239). Guilford Press.

Piedmont, R. L. (2001). Cracking the plaster cast: Big Five personality change during intensive outpatient counseling. Journal of Research in Personality, 35(4), $500-520$.

Polivy, J. in Herman, C. P. (2002). If at first you don't succeed: False hopes of self-change. American Psychologist, 57(9), 677-689.

Quintus, M., Egloff, B. in Wrzus, C. (2017). Predictors of volitional personality change in younger and older adults: Response surface analyses signify the complementary perspectives of the self and knowledgeable others. Journal of Research in Personality, 70, 214-228.

Roberts, B. W., Kuncel, N. R., Shiner, R., Caspi, A. in Goldberg, L. R. (2007). The power of personality: The comparative validity of personality traits, socioeconomic status, and cognitive ability for predicting important life outcomes. Perspectives on Psychological Science, 2, 313-345.

Roberts, B. W., Luo, J., Briley, D. A., Chow, P. I., Su, R. in Hill, P. L. (2017). A systematic review of personality trait change through intervention. Psychological Bulletin, 143, 117-141.

Roberts, B. W. in Mroczek, D. (2008). Personality trait change in adultdood. Current Directions in Psychological Science, 17, 31-35.

Roberts, B. W., Walton, K. E. in Viechtbauer, W. (2006). Patterns of mean-level change in personality traits across the life course: A metaanalysis of longitudinal studies. Psychological Bulletin, 132, 1-25.
Roberts, B. W. in Wood, D. (2006). Personality development in the context of the neo-socioanalytic model of personality. V D. K. Mroczek in T. D. Little (ur.), Handbook of personality development (str. 11-39). Lawrence Erlbaum Associates.

Robinson, O. C., Noftle, E. E., Guo, J., Asadi, S. in Zhang, X. (2015). Goals and plans for Big Five personality trait change in young adults. Journal of Research in Personality, 59, 31-43.

Sander, J., Schmiedek, F., Brose, A., Wagner, G. G. in Specht, J. (2017). Long-term effects of an extensive cognitive training on personality development. Journal of Personality, 85(4), 454-463.

Schimmack, U. (2012). The ironic effect of significant results on the credibility of multiple-study articles. Psychological Methods, 17, 551-566.

Sedlmeier, P., Eberth, J., Schwarz, M., Zimmermann, D., Haarig, F., Jaeger, S. in Kunze, S. (2012). The psychological effects of meditation: A meta-analysis. Psychological Bulletin, 138(6), 1139-1171.

Specht, J., Bleidorn, W., Denissen, J. J., Hennecke, M., Hutteman, R., Kandler, C., Luhmann, M., Orth, U., Reitz, A. K. in Zimmermann, J. (2014). What drives adult personality development? A comparison of theoretical perspectives and empirical evidence. European Journal of Personality, 28(3), 216-230.

Stieger, M., Nißen, M., Rüegger, D., Kowatsch, T., Flückiger, C. in Allemand, M. (2018). PEACH, a smartphoneand conversational agent-based coaching intervention for intentional personality change: study protocol of a randomized, wait-list controlled trial. $B M C$ Psychology, 6(1), 43-58.

Verbruggen, F., McLaren, I. P. in Chambers, C. D. (2014). Banishing the control homunculi in studies of action control and behavior change. Perspectives on Psychological Science, 9(5), 497-524.

Wrzus, C. in Roberts, B. W. (2017). Processes of personality development in adulthood: The TESSERA framework. Personality and Social Psychology Review, 21(3), 253-277. 